\title{
Biogeochemical processes and microbial diversity of the Gullfaks and Tommeliten methane seeps (Northern North Sea)
}

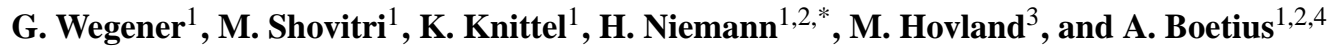 \\ ${ }^{1}$ Max Planck Institute for Marine Microbiology, Bremen, Germany \\ ${ }^{2}$ Alfred Wegener Institute for Polar and Marine Research, Bremerhaven, Germany \\ ${ }^{3}$ Statoil, Stavanger, Norway \\ ${ }^{4}$ Jacobs University Bremen, Bremen, Germany \\ *now at: Institute for Environmental Geosciences, University of Basel, Switzerland
}

Received: 21 January 2008 - Published in Biogeosciences Discuss.: 25 February 2008

Revised: 3 June 2008 - Accepted: 11 July 2008 - Published: 18 August 2008

\begin{abstract}
Fluid flow related seafloor structures and gas seeps were detected in the North Sea in the 1970s and 1980s by acoustic sub-bottom profiling and oil rig surveys. A variety of features like pockmarks, gas vents and authigenic carbonate cements were found to be associated with sites of oil and gas exploration, indicating a link between these surface structures and the underlying, deep hydrocarbon reservoirs. In this study we performed acoustic surveys and videographic observation at Gullfaks, Holene Trench, Tommeliten, Witch's Hole and the giant pockmarks of the UK Block 15/25, to investigate the occurrence and distribution of cold seep ecosystems in the Northern North Sea. The most active gas seep sites, i.e. Gullfaks and Tommeliten, were investigated in detail. At both sites, gas bubbles escaped continuously from small holes in the seabed to the water column, reaching the upper mixed surface layer. At Gullfaks a gas emitting, flat area of $0.1 \mathrm{~km}^{2}$ of sandy seabed covered by filamentous sulfur-oxidizing bacteria was detected. At Tommeliten, we found a patchy distribution of small bacterial mats indicating sites of gas seepage. Below the patches the seafloor consisted of sand from which gas emissions were observed. At both sites, the anaerobic oxidation of methane (AOM) coupled to sulfate reduction (SR) was the major source of sulfide. Molecular analyses targeting specific lipid biomarkers and 16S rRNA gene sequences identified an active microbial community dominated by sulfur-oxidizing and sulfate-reducing bacteria (SRB) as well as methanotrophic bacteria and archaea. Stable carbon isotope values of specific, microbial fatty acids and alcohols from both sites were highly depleted in the heavy isotope ${ }^{13} \mathrm{C}$, indicating that the
\end{abstract}

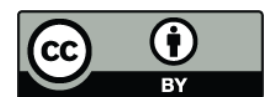

Correspondence to: $\mathrm{G}$. Wegener (gwegener@mpi-bremen.de) microbial community incorporates methane or its metabolites. The microbial community composition of both shallow seeps shows high similarities to the deep water seeps associated with gas hydrates such as Hydrate Ridge or the Eel River basin.

\section{Introduction}

The North Sea is a marginal sea of the Atlantic on the European continental shelf. Its sedimentary basin, especially the western and northern areas, hosts large gas and oil fields which are exploited since the 1970s. Leaking methane reservoirs are a major source for shallow gas accumulations and emissions into the water column and atmosphere (Hovland and Judd, 1988; Rehder et al., 1998; Judd and Hovland, 2007). In the North Sea, eruptive gas ebullition through impermeable seabed layers consisting of stiff glacial clays lead to the formation of craters, also known as pockmarks (Hovland and Judd, 1988). These pockmarks have diameters in the range of a few to several hundred meters and are widespread in gas and oil fields of the central and northern North Sea. Intensive bathymetric and videographic surveys by the British Geological Survey and the oil industry have led to a good understanding of the distribution of pockmarks and other gas escape structures in the North Sea (Judd and Hovland, 2007). As part of the 5th EU framework project METROL "Methane fluxes in ocean margin sediments: microbiological and geochemical control" we studied the distribution, biogeochemistry and microbiology of gas seepage in the North Sea, to identify potential sites of methane emission to the atmosphere, and to better understand the functioning of shallow water seep ecosystems.

Published by Copernicus Publications on behalf of the European Geosciences Union. 


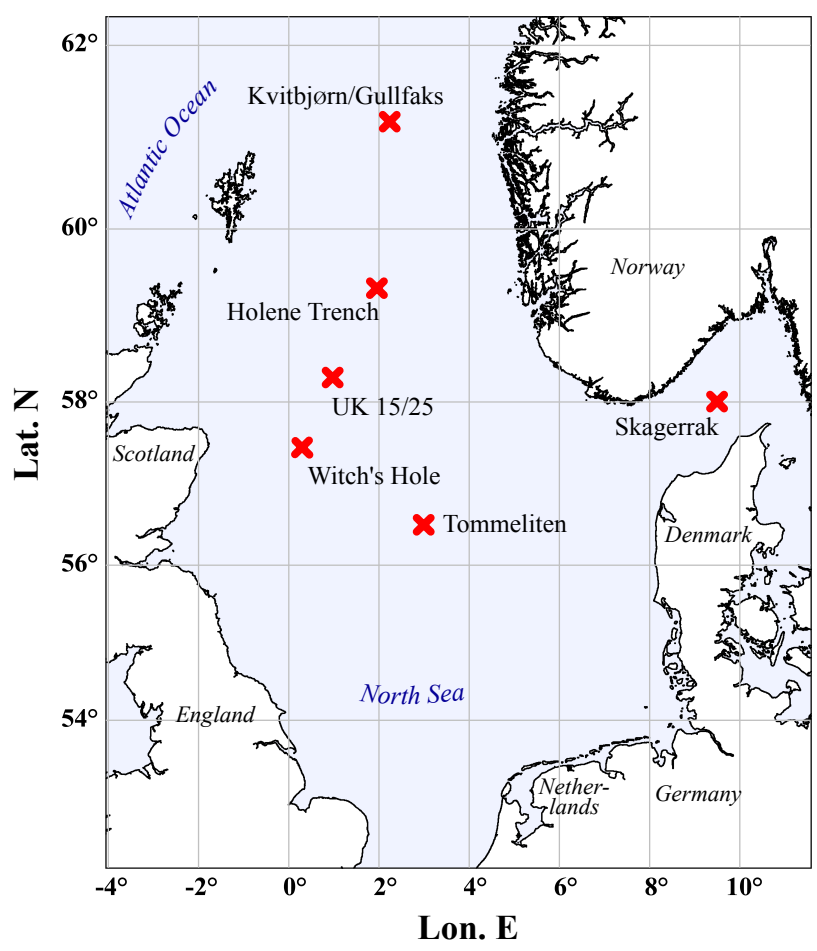

Fig. 1. Tommeliten, Gullfaks and other potential gas escape structures investigated for current gas emission during the METROL research expeditions HE 169, HE 180, HE 208 and Alkor 267.

Although methane is an abundant hydrocarbon in marine sediments, the oceans only account for 2 to $5 \%$ of the global methane flux to the atmosphere (Judd et al., 2002; Reeburgh, 2007). Aerobic and anaerobic microbial methane consumption almost completely controls the gas flux into the water column and atmosphere, except at sites of high fluid flow and free gas ebullition (Valentine and Reeburgh, 2000). The anaerobic oxidation of methane (AOM) with sulfate as the terminal electron acceptor is the dominant biogeochemical process in gassy sediments (Hinrichs and Boetius, 2002). Its net reaction can be described according to $\mathrm{R} 1$, but the underlying biochemistry of this process remains unknown (Widdel et al., 2007).

$\mathrm{CH}_{4}+\mathrm{SO}_{4}^{2-} \longrightarrow \mathrm{HCO}_{3}^{-}+\mathrm{HS}^{-}+\mathrm{H}_{2} \mathrm{O}$

In marine environments, 3 clades of archaea related to the order Methanosarcinales (ANME-1, -2, -3) were identified as anaerobic methanotrophs by analyses of 16S rRNA gene sequences as well as by stable isotope compositions of specific biomarkers (Hinrichs et al., 1999; Boetius et al., 2000; Orphan et al., 2001b; Niemann et al., 2006). In most seep habitats, methanotrophic archaea form consortia with sulfate-reducing bacteria (SRB) of the Desulfosarcina/Desulfococcus or Desulfobulbus groups (Boetius et al., 2000; Knittel et al., 2003; Niemann et al., 2006; Lösekann et al., 2007). These associations are commonly attributed to obligate syntrophy, in which the archaeal partner activates and metabolizes methane, providing a so far unidentified intermediate which is scavenged by the sulfatereducing partner (Nauhaus et al., 2002, 2007). Analyses of carbon isotopes in seep ecosystems have shown a tight link between methane, the microbial consortia, authigenic carbonate precipitates and higher trophic levels in the food web (Hovland and Sommerville, 1985; Ritger et al., 1987; Hinrichs and Boetius, 2002; Hovland et al., 2002; Levin, 2005). Deep water gas seeps often support an enormous biomass of free-living and symbiotic microbial life that is nourished by the oxidation of methane and the AOM product sulfide. A prominent feature of such seeps are mat-forming chemoautotrophic bacteria using sulfide as energy source, including Beggiatoa (Treude et al., 2003; Joye et al., 2004), and Arcobacter (Omoregie et al., 2008). Authigenic carbonates are often found associated with cold seeps, since AOM increases the pore water alkalinity (Luff and Wallmann, 2003). Carbonate outcrops were found to attract a variety of hardground fauna like corals, ophiurids, sponges and bivalves (Hovland and Risk, 2003; Niemann et al., 2005). Ultimately, the carbonate precipitation associated with AOM may fill and seal gas escape conduits (Hovland, 2002).

During the last decade biogeochemical research efforts on cold seeps mainly focused on deep water systems, especially those associated with gas hydrates. As a consequence, much more is known about these systems than about shallow water seeps in estuaries and shelf seas, despite their potential relevance for gas emission to the atmosphere. Specifically in the Northern North Sea where the water column is frequently mixed by storms, methane emission from the seabed is likely to result in an export of this greenhouse gas to the atmosphere.

Here we investigated several pockmarks and potential sites of gas seepage of the Northern North Sea. Sediments were sampled from sulfur-oxidizing bacterial mats which were associated with gas ebullition. Based on the concentration and stable carbon isotope values of specific lipid biomarkers, as well as by $16 \mathrm{~S}$ rRNA sequence analysis, we describe the microbial communities of two active shallow water seeps in the North Sea (Gullfaks and Tommeliten). Furthermore, their phylogenetic and biogeochemical characteristics are compared with those of known deep water cold seep communities to investigate whether shallow and deep water seeps are populated by different types of methanotrophs. 


\section{Material and methods}

\subsection{Sampling sites}

Figure 1 gives an overview on the cold seep sites in the North Sea visited during the METROL cruises (R/V Heincke cruises HE 169, HE 180, HE 208 and R/V Alkor cruise AL 267; see also Table 1). For all investigated sites, detailed background information were obtained previously during extensive geological surveys including seismic and sonar monitoring of seabed and water column features, as well as by videographic exploration using towed cameras and ROVs (Hovland and Judd, 1988). Gas emissions at Tommeliten and Gullfaks have been documented for a period over 25 years (Niemann et al., 2005; Judd and Hovland, 2007).

Gullfaks is one of the four major Norwegian oil and gas fields, located in the northeastern edge of the North Sea Plateau. Hovland (2007) named the area of acoustically detectable methane emission on the plateau 'Heincke seepage area'. The water depth in this area is ca. $150 \mathrm{~m}$ and deepens northeastwards towards the Norwegian trench. During the last glacial maximum the plateau was exposed and coastal sands were deposited. Younger sediments of the Holocene have not been found in this area because tidal currents prevent deposition (Eisma and Kalf, 1987). The Gullfaks hydrocarbon reservoir is situated in a depth of almost $3 \mathrm{~km}$ (Hovland and Judd, 1988). Shallow gas accumulations formed above the leaky reservoir at depths between 230 and 450 meters below the seafloor (mbsf). The stable carbon isotope composition of methane is -44.3 at reservoir level (2890 mbsf) and $-73.9 \%$ at $10 \mathrm{mbsf}$ (Hovland, 2007).

Tommeliten lies in the greater Ekofisk area in the central North Sea at a water depth of $75 \mathrm{~m}$ (Hovland and Judd, 1988; Hovland, 2002; Judd and Hovland, 2007). This gas field is associated with salt diapirs at about $1000 \mathrm{mbsf}$, and has already been fully exploited (Hovland, 2002). Seismic profiles indicate extensive gas escape pathways in the seabed above the deposit. The sediments consist of sands, silt and marl (Niemann et al., 2005). Associated with gas leakage pathways are calcareous cements, some of which extend above the seafloor and form small reefs populated by anthozoa and other hardground fauna (Hovland and Judd, 1988; Niemann et al., 2005). Acoustic turbidity indicated the presence of free gas in the seabed in an area of about $0.12 \mathrm{~km}^{2}$. Sonar surveys revealed gas escape to the water column, and accordingly, numerous gas seeps associated with whitish bacterial mats were observed during prior surveys (Hovland and Sommerville, 1985; Hovland and Judd, 1988; Trasher et al., 1996; Niemann et al., 2005). Gas seepage was confined to about 120 individual bubble streams in an area of $6500 \mathrm{~m}^{2}$ leading to an estimated emission of $47 \mathrm{~g} \mathrm{CH}_{4} \mathrm{~m}^{-2}$ in this area (Hovland et al., 1993). In the vicinity of the gas vents, elevated methane concentrations and gas bubbles were found in the seabed, at a sediment depth of 1-5 mbsf, associated with layers of carbonate precipitates and cements (Niemann et al., 2005). These observations and biogeochemical rate measurements indicate that most methane may be consumed in the seafloor, but that considerable gas escape to the water column occurs through cracks and fissures (Niemann et al., 2005). The carbon isotope composition of methane indicates its thermogenic origin (Hovland and Sommerville, 1985; Hovland and Judd, 1988). Biomarker analyses suggested that AOM in subsurface sediments was mediated by ANME-1, and it was speculated that an ANME-2 community may dominate gas consumption in vented surface sediments as indicated by the biomarker signature preserved in the authigenic carbonate outcrops in the seep area (Niemann et al., 2005).

\subsection{Seafloor observations}

During the cruises HE 169, HE 180, HE 208 and AL 267 (Table 1), several seep locations of the North Sea were visited (Fig. 1). Gas flares were detected using the sediment echo sounder system SES-2000 provided by INNOMAR (Rostock, Germany). The emitter induces two primary frequencies near $100 \mathrm{kHz}$ to generate secondary bandwidths of 4 and $15 \mathrm{kHz}$. Water depth and gas flares were recorded with the 15 $\mathrm{kHz}$ spectrum, while sediment features were observed with a $4 \mathrm{kHz}$ spectrum. Several acoustic transects were evaluated to quantify the gas flares and their extensions, and to localize flare sources at the seafloor. Video observations were performed with the remotely operated vehicle (ROV) Sprint (Alfred Wegener Institute for Polar and Marine Research, Bremerhaven; HE 169) or Cherokee (MARUM, Bremen; AL 267) and a towed camera system of the AWI (HE 180) or the MPI (HE 208; Spy, Mariscope, Kiel).

\subsection{Sediment sampling}

At the Heincke seep at Gullfaks, sediments were sampled in May 2004 (HE 208) using a video-guided multiple corer system (MUC; Octopus, Kiel). The samples were recovered from an area densely covered with bacterial mats where gas ebullition was observed. The coarse sands limited MUC penetration depth to max 30 centimeters and the highly permeable sands did not allow for a high-resolution, vertical subsampling because of pore water loss.

The gas flare mapping and videographic observation at Tommeliten indicated an area of gas emission with a few small patches of bacterial mats with diameters $<50 \mathrm{~cm}$ from most of which a single stream of gas bubbles emerged. The patches were spaced apart by $10-100 \mathrm{~m}$. Sampling of sediments covered by bacterial mats was only possible with 3 small push cores ( $3.8 \mathrm{~cm}$ diameter) mounted to ROV Cherokee. These cores were sampled in $3 \mathrm{~cm}$ intervals.

Sediment porosity, sulfate and methane concentrations were determined according to standard methods (see METROL protocols at: http://www.metrol.org/index.php? bereich=1). In situ methane concentrations were calculated 
Table 1. Visited gas escape structures and the presence of gas flares and methane-derived carbonates. The cruises took place in June 2002 (HE 169), October 2002 (HE 180), May 2004 (HE 208), and September 2005 (AL 267).

\begin{tabular}{lllllll}
\hline Structure & Latitude & Longitude & Water depth & Cruise & Gas escape & Authigenic carbonates \\
\hline Gullfaks seep & $61^{\circ} 10.40^{\prime}$ & $02^{\circ} 14.50^{\prime}$ & $150 \mathrm{~m}$ & HE 169, HE 180, AL 267 HE 208 & yes & no \\
Holene Trench & $59^{\circ} 19.60^{\prime}$ & $01^{\circ} 57.60^{\prime}$ & $130-145 \mathrm{~m}$ & HE 169 & no & yes* \\
UK 15/25 pockmarks & $58^{\circ} 17.00^{\prime}$ & $00^{\circ} 58.50^{\prime}$ & $155-170 \mathrm{~m}$ & HE 180, HE 208 & yes & yes \\
Witch's Hole & $57^{\circ} 56.50^{\prime}$ & $00^{\circ} 23.30^{\prime}$ & $135 \mathrm{~m}$ & HE 208 & no & yes* \\
Snow White's Hole & $57^{\circ} 58.81^{\prime}$ & $00^{\circ} 23.30^{\prime}$ & $145 \mathrm{~m}$ & HE 208 & yes & n.a. \\
Tommeliten & $56^{\circ} 29.90^{\prime}$ & $02^{\circ} 59.80^{\prime}$ & $75 \mathrm{~m}$ & HE 169, HE 180, AL 267 & yes & yes \\
Skagerrak pockmarks & $58^{\circ} 00.00^{\prime}$ & $09^{\circ} 40.00^{\prime}$ & $120-150 \mathrm{~m}$ & HE 208 & no & no* \\
\hline
\end{tabular}

n.a.: bottom observations were not available

* described in Judd and Hovland (2007)

using PHREEQC, Version 2, US Geological Survey, 2007. Samples for molecular, microbiological and biomarker analyses were processed as described below.

Radiotracer based in vitro measurements of AOM and SR were performed in the home laboratory. Sediment samples stored anaerobically in wide mouth bottles with artificial, anaerobic seawater medium (Widdel and Bak, 1992) were transferred into Hungate tubes, refilled with medium and brought into equilibrium with one atmosphere of methane (Krüger et al., 2005). Controls without methane addition were prepared to determine methane-independent SR. AOM and SR rates were determined from replicate incubations $(n \geq 3)$. After one day of equilibration, ${ }^{35} \mathrm{SO}_{4}(50 \mathrm{kBq}$ dissolved in $10 \mu \mathrm{l}$ water) for SR and ${ }^{14} \mathrm{CH}_{4}(10 \mathrm{kBq}$ dissolved in $50 \mu \mathrm{l}$ water) for AOM were injected into the Hungate tubes through a butyl rubber septum. Samples were incubated for 7 days at $8^{\circ} \mathrm{C}$. The reactions were stopped by transferring the samples into zinc acetate and $\mathrm{NaOH}$ solution, respectively (Treude et al., 2003). Further processing of AOM and SR samples was carried out as described previously (Treude et al., 2003; Kallmeyer et al., 2004). Concentrations and activities of the reactants (methane or sulfate) and the activities of the products (sulfide or carbonate) were measured to determine AOM and SR rates according to the following formulas:

AOM rate $=\frac{\left[\mathrm{CH}_{4}\right] \cdot a^{14 \mathrm{C}} \text { carbonate }}{t \cdot a^{14 \mathrm{C}} \text { methane }}$

$\mathrm{SRR}=\frac{\left[\mathrm{SO}_{4}\right] \cdot a_{\mathrm{TRIS}}}{t \cdot a_{\mathrm{TOT}}} \cdot 1.06$

In Eq. (1) $\left[\mathrm{CH}_{4}\right]$ is the concentration of methane, $a^{14 C}$ methane and $a^{14 \mathrm{C}}$ carbonate the activity of the reactant and the product of AOM (Treude et al., 2003). In Eq. (2), [SO4] is the concentration of sulfate, $a_{\text {TRIS }}$ the activity of the total reduced inorganic sulfur, $a_{\text {TOT }}$ is the total activity of sulfide and sulfate and $t$ is the reaction time. The factor 1.06 accounts for the discrimination against the heavier radio nucleotide ${ }^{35} \mathrm{~S}$ (Jørgensen and Fenchel, 1974).

Total organic carbon content (TOC) and carbon nitrogen ratios $(\mathrm{C} / \mathrm{N})$ were analyzed from freeze-dried samples.
Briefly, inorganic carbon (carbonate) was removed via $\mathrm{HCl}$ acidification. Subsequently, 20 to $30 \mathrm{mg}$ of homogenized samples were filled in zinc cartridges and organic carbon and nitrogen was measured in a CNS analyzer (Carlo Erba NA 1500 CNS analyzer).

\subsection{Biomarker analysis}

Lipid biomarker extraction from $10-17 \mathrm{~g}$ wet sediment was carried out as described in detail elsewhere (Elvert et al., 2003). Briefly, defined concentrations of cholestane, nonadecanol and nonadecanolic acid with known $\delta^{13} \mathrm{C}$-values were added to the sediments prior to extraction as internal standards for the hydrocarbon, alcohol and fatty acid fraction, respectively. Total lipid extracts were obtained from the sediment by ultrasonification with organic solvents of decreasing polarity. Esterified fatty acids (FAs) were cleaved from the glycerol head group by saponification with methanolic $\mathrm{KOH}$ solution. From this mixture, the neutral fraction was extracted with hexane. After subsequent acidification, FAs were extracted with hexane. For analysis, FAs were methylated using $\mathrm{BF}_{3}$ in methanol yielding fatty acid methyl esters (FAMES).

The neutral fraction was further separated into hydrocarbons, ketones and alcohols on SPE cartridges with solvents of increasing polarity (Niemann et al., 2005). The ketone fraction was not further analyzed. Shortly before analysis, alcohols were methylated to trimethylsilyl (TMS) ethers using bis(trimethylsilyl)triflouracetamid (BSTFA). Concentration and identity of single lipid compounds was determined by gas chromatography (GC) and gas chromatography-mass spectrometry (GC-MS) analysis, respectively (Elvert et al., 2003, 2005; Niemann et al., 2005). Double bound positions of monounsaturated FAs were determined analyzing their dimethyl disulfide (DMDS) adducts according to Moss and Labert-Faeir (1989). $\delta^{13} \mathrm{C}$-values of single lipid compounds were determined by GC-IRMS analyses according to Elvert et al. (2003). Concentration and carbon stable isotopic compositions of FAs and alcohols were corrected for the additional carbon atoms added during derivatisation. 
2.5 DNA extraction, PCR amplification and clone library construction

DNA was extracted from $2 \mathrm{~g}$ of wet sediment $(1-3 \mathrm{~cm}$ depth) using the Bio101 soil kit (Bio101, La Jolla, California). Domain-specific primers, i.e, GM3F (Muyzer et al., 1995) and EUB1492 (Kane et al., 1993) for Bacteria and ARCH20F (Massana et al., 1997) and Uni1392 (Lane et al., 1985) for Archaea, were used to amplify almost full-length 16S rRNA genes from the extracted chromosomal DNA by PCR (30 cycles). PCR products were purified as described previously (Ravenschlag et al., 1999). DNA was ligated in the pGEMT-Easy vector (Promega, Madison, WI) and transformed into E. coli TOP10 cells (Invitrogen, Carlsbad, CA, USA) following manufacturer's recommendation.

\subsection{Sequencing and phylogenetic analysis}

Sequencing was performed by Taq cycle sequencing with a model ABI377 sequencer (Applied Biosystems). The presence of chimeric sequences in the clone libraries was determined with the CHIMERA_CHECK program of the Ribosomal Database Project II (Center for Microbial Ecology, Michigan State University, http://rdp8.cme.msu.edu/ cgis/chimera.cgi?su=SSU). Sequence data were analyzed with the ARB software package (Ludwig et al., 2004). Phylogenetic trees were calculated with the sequences from this project together with reference sequences, which were available in the EMBL, GenBank and DDJB databases by maximum-likelihood and neighbor-joining analysis with different sets of filters. The sequence data reported here will appear in the EMBL, GenBank, and DDBJ nucleotide sequence databases under the accession no. FM179815-179920.

2.7 Cell counts and CARD-FISH (Catalyzed reporter deposition - fluorescence in situ hybridization)

The fixation for total cell counts and CARD-FISH were performed on-board directly after sampling. For both methods, sediments were fixed in formaldehyde solution. After two hours, aliquots for CARD-FISH staining were washed with $1 \times$ PBS $(10 \mathrm{mM}$ sodium phosphate solution, $130 \mathrm{mM}$ $\mathrm{NaCl}$, adjusted to a $\mathrm{pH}$ of 7.2) and finally stored in a 1:1 PBS:ethanol solution at $-20^{\circ} \mathrm{C}$ until further processing. Samples for total cell counts were stored in formalin at $4^{\circ} \mathrm{C}$ until analysis.

For sandy samples, the total cell count/CARD-FISH protocol was optimized to separate sand particles from the cells. Cells were dislodged from sediment grains and brought into solution with the supernatant by sonicating each sample on ice for $2 \mathrm{~min}$ at $50 \mathrm{~W}$. This procedure was repeated four times and supernatants were combined. Total cell numbers were determined from the supernatant by fluorescence microscopy subsequently to acridine orange staining (Meyer-Reil, 1983).
CARD-FISH was performed following the protocol of Pernthaler et al. (2002). The sediment samples were brought to a final dilution of 1:2000 to 1:4000 and filtered onto $0.2 \mu \mathrm{m}$ GTTP filters (Millipore, Eschbonn, Germany). The probes used in this study (purchased from biomers.net GmbH, Ulm, Germany) were EUB 338 specific for most Bacteria (Amann et al., 1990; Daims et al., 1999), DSS658 specific for Desulfosarcina spp., Desulfococcus spp. and closely related clone sequences (Manz et al., 1998), Arch915 specific for most Archaea (Stahl and Amann, 1991), and probes ANME1-350 (Boetius et al., 2000), ANME2a647, ANME2c-622 (Knittel et al., 2005) and ANME3-1249 (Niemann et al., 2006) specific for ANME-1, -2a, -2c, and -3 Archaea, respectively. Cell permeabilization and probe hybridization were performed according to the author's instructions. For reference cell numbers, samples were also stained with 4'6'-diamidino-2-phenlyindole (DAPI) for $15 \mathrm{~min}(1 \mu \mathrm{g} / \mathrm{ml})$ and washed with sterile filtered water and ethanol for 60 and $30 \mathrm{~s}$, respectively. Air-dried filters were imbedded in Citifluor (Citifluor Ltd., Leicester, UK). Cells were counted using an epifluorescence microscope (Axioplan, Zeiss, Germany). At least 1000 cells in randomly chosen fields were counted per sample. To quantify aggregates of ANME-2a, $-2 \mathrm{c}$ and -3 , up to 250 grids were counted under 400-fold magnification. Dual hybridizations for sulfate reducers (DSS) and archaea (ANME-2a and -2c) were performed using different fluorescence dyes (Cy3 and $\mathrm{Cy} 5)$ and images were taken with a confocal laser scanning microscope (LSM510; Carl Zeiss, Jena, Germany). The relatively low detection ratio of $<60 \%$ of total cells in sediments from the Heincke Seep may be a result of the harsh sonication procedures necessary to obtain cells attached to sand grains.

\section{Results and discussion}

\subsection{Distribution of active seeps in the Northern North Sea}

Active methane seepage from the seabed was detected at different fluid flow-related seafloor structures visited during the METROL cruises (Fig. 1, Table 1). Large and abundant gas flares were found at Gullfaks (Fig. 2a), the giant pockmarks of UK block 15/25 (Fig. 2c); Snow White's Hole (Fig. 2d), and Tommeliten (Fig. 2e).

The pockmarks of UK Block 15/25, Snow White's Hole and Witch's Hole are part of the Witch Ground formation, northwest of the Tommeliten seep area (Fig. 1, Hovland and Judd, 1988). During our observation at UK Block 15/25 (HE 180 and HE 208), most of the 5 giant pockmarks (characterized by a depression of more than $10 \mathrm{~m}$ below ambient seafloor; Scanner, Scotia and Challenger) and two medium sized pockmarks ( $\sim 5 \mathrm{~m}$ depressions) showed active seepage of methane from the deepest part of each depression (Fig. 2c). The highest gas flares were observed to reach up to $80 \mathrm{~m}$ below sea surface. The pockmark centers were 

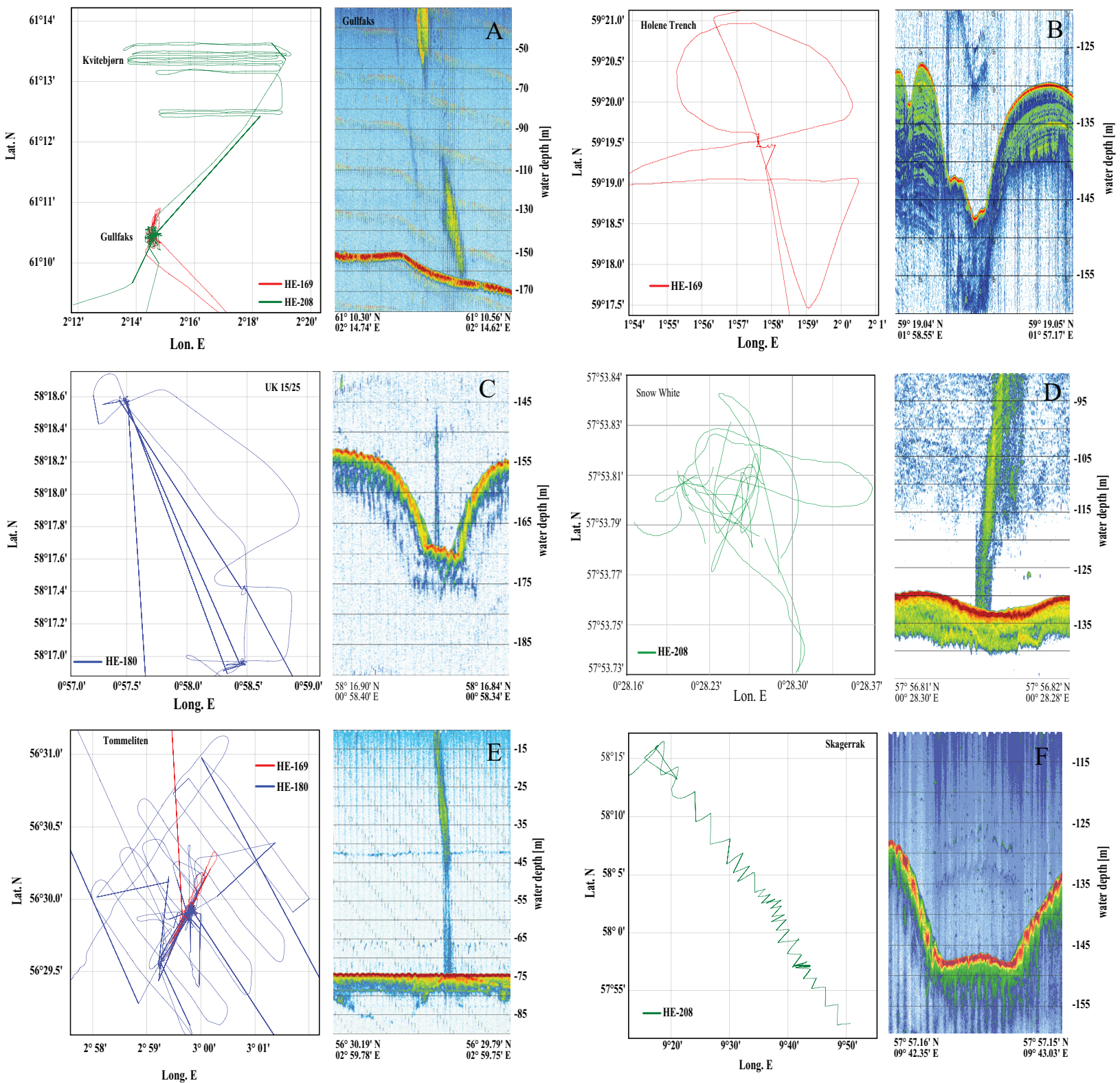

Fig. 2. Survey tracks and exemplary SES-2000 echo images showing gas flares and sea floor structures of Heincke seep area at Gullfaks (A), Holene Trench (B), Scanner pockmark (UK 15/25 field) (C), Snow White's Hole (D), Tommeliten (E). and Skagerrak (F). Note that the structure visualized in the water column of Holene Trench is a reflection of the seafloor.

paved with carbonate outcrops, which were populated with benthic organisms, mostly sea anemones. As neither MUC nor gravity corer were able to penetrate the cements, no sediment samples could be recovered for biogeochemical analyses. Methane venting at the pockmarks in the UK Block 15/25 has already been observed previously by Hovland and Judd (1988) as well as during the METROL expeditions over the last 5 years. This indicates that the pockmarks may have been continuously emitting methane to the hydrosphere for at least two decades.

In contrast to earlier observations (Hovland and Judd, 1998), the Witch's Hole structure was dormant during our observations. However, we found an active pockmark $(15 \mathrm{~km})$ to the southwest, which we named Snow White's Hole (Fig. 2d). This structure emits a large gas flare extending to about $80 \mathrm{~m}$ above the seafloor. Unfortunately sediment sampling directly at the flare was not possible, probably because of carbonate cements and coring at the edge of the pockmark recovered only non-seep sediments.

The Holene Trench is an open channel of ca. $1 \mathrm{~km}$ width on the Norwegian Plateau at $\sim 120 \mathrm{~m}$ water depth. Previous surveys showed an acoustic turbidity in the topmost $30 \mathrm{~m}$ of the surface sediments indicating gas charged sediments (Hovland and Judd, 1988). During our survey, two areas 

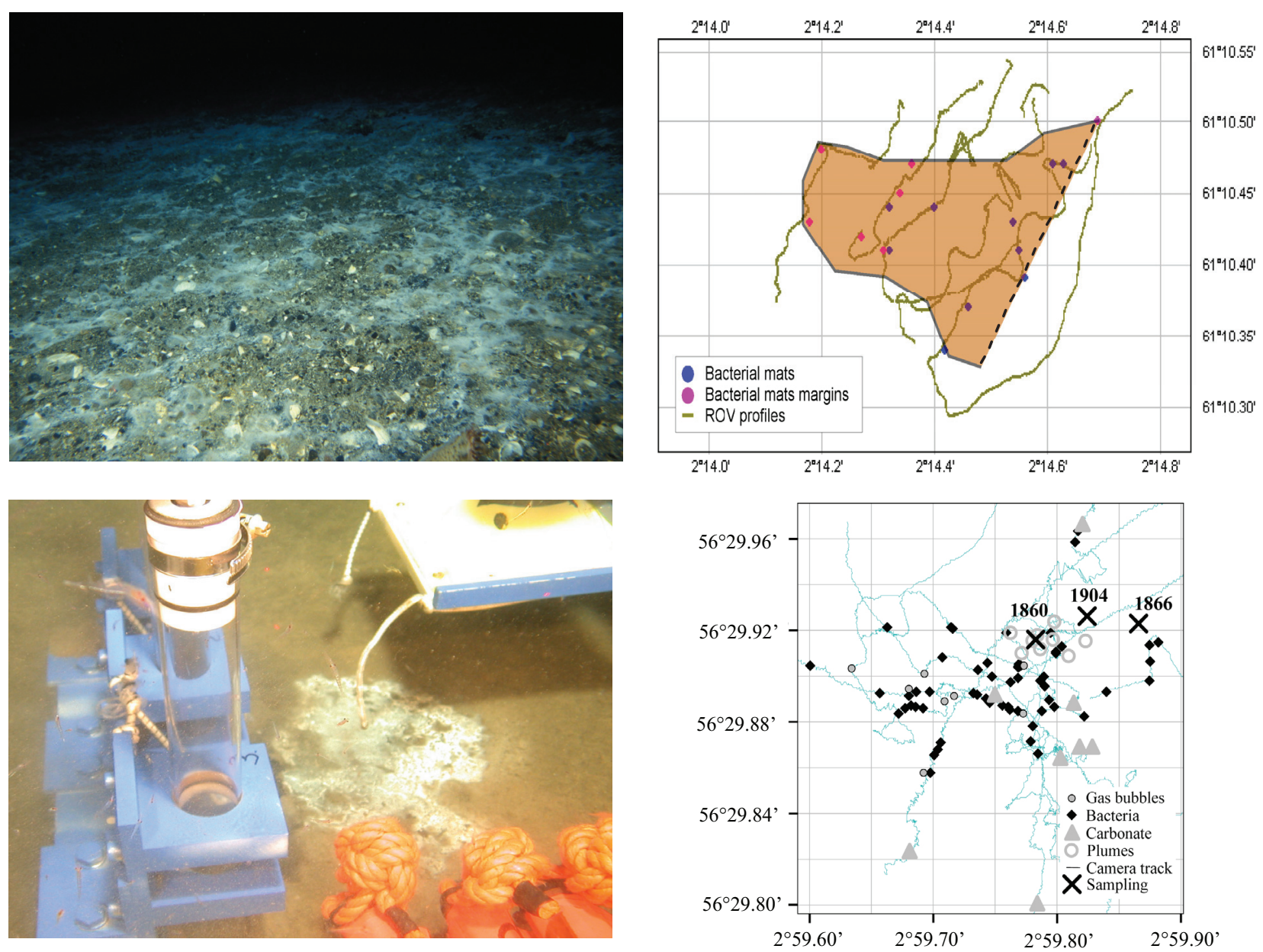

Fig. 3. Upper half: Mats of giant sulfur-oxidizing bacteria covering coarse sands and pebbles at the Heincke seep area at Gullfaks (left panel). The mats coincide with the area of gas ebullition and cover an area of about $0.1 \mathrm{~km}^{2}$ (right panel). Lower half: Bacterial mats of the Tommeliten gas seep. Sampling of a mat patch with a diameter of about $30 \mathrm{~cm}$ (left panel). Gas ebullition was observed during sampling. Map showing the distribution of mats, gas flares and carbonates (right panel; after Niemann et al. 2005).

were found where the turbidity extends to the surface of the sea floor. However, during HE169 we could not find any traces for active seepage (Fig. 2b) with hydro-acoustic methods and only oxidized beige-colored, clayish sediments were retrieved by multiple corer sampling. The western slope of the Norwegian Trench hosts several pockmark-like structures, which do not bear carbonate outcrops (Hovland and Judd, 1988). Similar to the Holene Trench our survey during cruise HE 169 did not reveal any traces of seepage in this area. In Skagerrak, several pockmarks with active gas escapes and seepage related fauna were discovered in the 1990s (Dando et al., 1994; Rise et al., 1999). However, during HE 208 we did not observe gas seepage from the positions reported by Dando et al. (1994) (Fig. 2f).

To further investigate the biogeochemistry and microbiology of shallow water cold seeps in the North Sea, we centered our efforts on the most active and accessible seep sites, i.e. the Heincke Seep at Gullfaks and the Tommeliten seep.
The results from subsurface sampling by vibrocoring at the Tommeliten seeps have already been reported by Niemann and colleagues (2005). In the present paper, we focus on surface sediments of gas vents associated with bacterial mats.

\subsection{Heincke seep area (Gullfaks)}

\subsubsection{Seafloor observations}

At the Heincke Seep area gas flares were found in an area of about $0.5 \mathrm{~km}^{2}$. which extended up to $120 \mathrm{~m}$ above the seafloor, reaching the mixed water layer (Fig. 2a). Considering the observation of free gas at a water depth of $150 \mathrm{~m}$ dissolved methane concentrations at the gas vents should be saturated and hence exceed $26 \mathrm{mM}$. Visual observations of the seafloor showed 1-2 bubble streams escaping from the sands every $5 \mathrm{~m}^{2}$ within a smaller area of $0.1 \mathrm{~km}^{2}$ covered by microbial mats (Fig. 3a). No megafauna was observed to populate the seep site or to graze upon the bacterial mats. The 
Table 2. Biomarker concentrations and their isotopic signatures in sediments from bacterial mat covered sands (Gullfaks Station 766), and sediments (Tommeliten Station 1274-K3) as well as from the subsurface SMTZ of Tommeliten (155 cm data by Niemann et al., 2005).

\begin{tabular}{|c|c|c|c|c|c|c|}
\hline \multirow[b]{2}{*}{ Compound } & \multicolumn{2}{|c|}{$\begin{array}{l}\text { Gullfaks Station } 766 \\
\quad(0-10 \mathrm{~cm})\end{array}$} & \multicolumn{2}{|c|}{$\begin{array}{l}\text { Tommeliten } 1274-\mathrm{K} 3 \\
(0-10 \mathrm{~cm})\end{array}$} & \multicolumn{2}{|c|}{$\begin{array}{c}\text { Tommeliten Core } 1904 \\
155 \mathrm{~cm} \text { SMTZ }\end{array}$} \\
\hline & $\mu \mathrm{ggdw}^{-1}$ & $\delta^{13} \mathrm{C}$ VPDB (\%o) & $\mu \mathrm{ggdw}^{-1}$ & $\delta^{13} \mathrm{C}$ VPDB $(\% \circ)$ & $\mu \mathrm{ggdw}^{-1}$ & $\delta^{13} \mathrm{C}$ VPDB (\%o) \\
\hline $\mathrm{C}_{14: 0}$ & 1.27 & -60 & 0.64 & -30 & 0.15 & -28 \\
\hline $\mathrm{i}-\mathrm{C}_{15: 0}$ & 0.61 & -41 & 0.30 & -35 & 0.06 & -43 \\
\hline ai- $\mathrm{C}_{15: 0}$ & 0.64 & -42 & 0.43 & -34 & 0.14 & -43 \\
\hline $\mathrm{C}_{15: 0}$ & 0.40 & -48 & 0.22 & -38 & 0.07 & -37 \\
\hline $\mathrm{C}_{16: 1 \omega 7 c}$ & 24.04 & -59 & 2.54 & -38 & 0.02 & -38 \\
\hline $\mathrm{C}_{16: 1 \omega 5 c}$ & 3.79 & -77 & 0.39 & -51 & 0.01 & n.a. \\
\hline $\mathrm{C}_{16: 0}$ & 6.17 & -46 & 1.93 & -32 & 0.60 & -31 \\
\hline $10 \mathrm{Me}-\mathrm{C}_{16: 0}$ & 0.45 & -39 & 0.21 & -33 & 0.02 & n.a. \\
\hline $\mathrm{i}-\mathrm{C}_{17: 0}$ & 0.12 & n.d. & 0.06 & -39 & 0.04 & n.a. \\
\hline ai- $\mathrm{C}_{17: 0}$ & 0.09 & n.d. & 0.07 & -37 & 0.04 & n.a. \\
\hline cy- $\mathrm{C}_{17: 0 \omega 5.6}$ & 0.24 & -40 & 0.27 & -59 & n.a. & n.a. \\
\hline $\mathrm{C}_{17: 0}$ & 0.16 & -36 & 0.08 & -29 & 0.04 & n.a. \\
\hline isoprenFA-C $\mathrm{C}_{19: 0}$ & 0.38 & -34 & 0.13 & -27 & n.a. & n.a. \\
\hline $\mathrm{C}_{18: 1 \omega 9 c}$ & 0.91 & -37 & 0.65 & -26 & 0.27 & n.a. \\
\hline $\mathrm{C}_{18: 1 \omega 7 c}$ & 6.65 & -41 & 1.60 & -45 & 0.06 & -32 \\
\hline $\mathrm{C}_{18: 0}$ & 0.35 & -37 & 0.32 & -30 & 0.35 & -34 \\
\hline Diplopterol & 0.43 & -84 & n.d. & n.d. & n.a. & n.a. \\
\hline archaeol & 0.05 & -115 & 0.05 & -86 & 0.47 & -61 \\
\hline sn2-hydro.arch. & 0.16 & -117 & 0.31 & -90 & 0.08 & -80 \\
\hline
\end{tabular}

n.d.: not detected

n.a.: not available

top $30 \mathrm{~cm}$ of sediment recovered by MUC-coring from the bacterial mat site was coarse to medium grained sands with an average sediment porosity of $33 \%$. During our ROV dives we observed ripple structures on the sandy seafloor which indicate at least episodically high water currents.

Upon recovery, of sediment samples from the bacterial mat field (Fig. 3a) the sediment cores degassed strongly, releasing methane bubbles into the overlaying water. Only the top surface layer of 1 to $5 \mathrm{~cm}$ was of beige color mixed with black particles, while deeper sediment layers were blackish. The color shift from beige to blackish sediments indicates the depth of the redox transition zone between oxidized surface sediments and reduced conditions below including the presence of free sulfide (also indicated by a strong smell of sulfide) and iron sulfide precipitations. Ferromagnetic minerals, probably magnetite or greigite, were found in reduced sediment layers, pointing to a possible connection of methane and iron geochemistry. The total organic carbon content was very low with only $0.17 \%$, indicating that sulfate reduction is rather coupled to methane oxidation than to deposited organic matter.

\subsubsection{Microbial methane oxidation and sulfate reduction}

Six multicorer samples were retrieved from the bacterial mat covered area. Methane oxidation and sulfate reduction rate (SRR) measurements were performed in all cores using replicate subsamples of bulk sediments (top $25 \mathrm{~cm}$ ). Methane oxidation rates ranged from $0.01 \mu \mathrm{mol} \mathrm{g}^{-1}$ to $0.18 \mu \mathrm{mol} \mathrm{g}^{-1}$ dry weight $\mathrm{d}^{-1}$ (mean: $0.12 \mu \mathrm{mol} \mathrm{g}^{-1}$ dry weight $\mathrm{d}^{-1}$ ) and sulfate reduction rates from $0.05 \mu \mathrm{mol} \mathrm{g}^{-1}$ to $0.30 \mu \mathrm{mol} \mathrm{g}^{-1}$ dry sediment $\mathrm{d}^{-1}$ (mean: $0.19 \mu \mathrm{mol} \mathrm{g}^{-1}$ dry weight $\mathrm{d}^{-1}$ ). In control measurements without methane, SRR was negligible, indicating that methane was the dominant electron donor for sulfate reduction. The integrated methane oxidation rates averaged $12.5 \mathrm{mmol} \mathrm{m}^{-2} \mathrm{~d}^{-1}$ and the integrated SRR $18.5 \mathrm{mmol} \mathrm{m}^{-2} \mathrm{~d}^{-1}$. These rates are comparable to other measurements from bacterial mat covered seep sites like Hydrate Ridge (5 to $99 \mathrm{mmol} \mathrm{m}^{-2} \mathrm{~d}^{-1}$; Treude et al., 2003) or Haakon Mosby Mud Volcano $\left(4.5 \mathrm{mmol} \mathrm{m}^{-2} \mathrm{~d}^{-1}\right.$; Niemann et al., 2006). According to our results, methane oxidation rates roughly amount to $15 \mathrm{t} \mathrm{yr}^{-1}$ for the area covered by bacterial mats $\left(0.1 \mathrm{~km}^{2}\right)$. Based on quantifications of single gas bubble streams (Hovland et al., 1993), we estimated a gas flux of $76 \mathrm{t} \mathrm{yr}^{-1}$ to the water column for this area. Consequently, the microbial filter consumes at least $16 \%$ of the 
total gas flux. However, the gas flux may vary strongly in intensity and methane content with time.

\subsubsection{Biomarker and stable carbon isotope compositions.}

Monounsaturated fatty acids (FAs) were strongly dominant in surface sediments of Gullfaks (Table 2). Although these FAs are produced by a wide range of gram-negative bacteria (Fang et al., 2005), their relative abundance can be used to trace specific microbial groups. The measured ratio for $\mathrm{C}_{16: 1 \omega 7 c}, \mathrm{C}_{18: 1 \omega 7 c}$ and $\mathrm{C}_{16: 0}$ of 68:18:14 approximates the ratio of 73:18:9 previously reported for Beggiatoa filaments covering cold seep sediments in the Gulf of Mexico (Zhang et al., 2005). The $\delta^{13} \mathrm{C}$-values of the $\mathrm{FA} \mathrm{C}_{16: 1 \omega 7 c}$ and $\mathrm{C}_{18: 1 \omega 7 c}$ ( -59 and $-41 \%$, respectively) indicate a substantial contribution of autotrophic carbon fixation as previously found for several species of giant filamentous sulfide oxidizers (Nelson and Jannasch, 1983; Nelson et al., 1986, 1989). Substantial amounts of the hopanoid diplopterol and its highly depleted carbon isotopic composition $\left(\delta^{13} \mathrm{C}-84 \%\right.$ ) indicates an origin from aerobic methanotrophic bacteria (Ourisson et al., 1979; Rohmer et al., 1984; Elvert and Niemann, 2008).

The $\delta^{13} \mathrm{C}$-depleted FAs $\mathrm{C}_{16: 1 \omega 5 c}$, cy(cyclopropane) $\mathrm{C}_{17: 0 \omega 5,6}$ as well as the iso- and anteiso-branched $\mathrm{C}_{15: 0}$ isomers were found in the Gullfaks samples. Those compounds have shown to be characteristic lipids for seep associated, sulfate-reducing proteobacteria (Elvert et al., 2003; Blumenberg et al., 2004; Niemann et al., 2005). The ratio of $\mathrm{C}_{16: 1 \omega 5 c}$ relative to $\mathrm{i}-\mathrm{C}_{15: 0}(6.2)$ is within the typical range (2-8) reported from populations of sulfate reducers associated to ANME-2 (Seep-SRB1) and -3 (Desulfobulbus) (Niemann and Elvert, 2008). From the difference in the carbon isotope composition of the seep specific FAs (e.g. $\delta^{13} \mathrm{C} \mathrm{C}_{16: 1 \omega 5 c}=-77 \%$ o, $\delta^{13} \mathrm{C}_{\text {aiC }} \mathrm{C}_{15: 0}=-40 \%$ o), it appears that a diverse community of sulfate reducers is present in the Gullfaks sediments, of which only some are coupled directly to anaerobic methanotrophy.

All known groups of marine ANME produce siginificant amounts of ${ }^{13} \mathrm{C}$-depleted archaeol and/or sn2hydroxyarchaeol, which are used as biomarkers for AOM (Hinrichs et al., 1999; Orphan et al., 2001a; Michaelis et al., 2002; Blumenberg et al., 2004; Niemann et al., 2006). At Gullfaks, sn2-hydroxyarchaeol was 3-fold more abundant than archaeol, indicating the dominance of ANME-2 populations (Blumenberg et al., 2004; Niemann and Elvert, 2008). Both compounds were highly depleted in ${ }^{13} \mathrm{C}$, with $\delta^{13} \mathrm{C}$-values of $-115 \%$ ond $-117 \%$. Assuming that methane was the sole carbon source $\left(\delta^{13} \mathrm{C}\right.$-methane $\sim-70 \%$, Judd and Hovland, 2007) for the synthesis of archaeol and sn2hydroxyarchaeol, this is equivalent to a ${ }^{13} \mathrm{C}$-fractionation of -45 to $-47 \%$. This is in the range of stable carbon isotope fractionation factors previously reported for ANME from different marine settings (Hinrichs and Boetius, 2002; Niemann and Elvert, 2008).
3.2.4 Microbial diversity and community composition based on 16S rRNA gene analyses

The bacterial 16S rRNA gene sequence library from surface sediments of the microbial mat habitat at Gullfaks comprised 70 sequences and was clearly dominated by microorganisms associated with seep ecosystems. We found different groups of sulfate-reducing bacteria and thiotrophic as well as methylotrophic bacteria (Table 3, Fig. 4). 15 sequences belonged to relatives of sulfur-oxidizing symbiotic Gammaproteobacteria usually hosted by different marine worms or bivalves. No sequences of filamentous sulfide oxidizers were found, although these bacteria were visually present in the sample from which DNA was extracted. Sequences related to methylotrophic bacteria (Methylomonas and Methylophaga relatives) were also abundant (6 sequences) matching our results from the biomarker studies. In accordance with the biomarker survey, we found 10 sequences of Deltaproteobacteria related to the Desulfosarcina/Desulfococcus group (Seep-SRB-1), which is the sulfate-reducing partner of ANME-1 and -2 (Boetius et al., 2000; Orphan et al., 2001a, b; Knittel et al., 2003). Nineteen clones were related to the cluster of Cytophaga - Flavobacterium - Bacteriodetes (CFB) which is a diverse group of bacteria commonly found in the plankton and sediment involved in the degradation of complex organic matter, but which also occur at cold seep ecosystems (Knittel et al., 2003).

The archaeal 16S rRNA gene sequence library was strongly dominated by Euryarchaeota sequences. Sixtythree out of 69 clones were affiliated with ANME-2a (Table 3, Fig. 5), the most common group of anaerobic methane oxidizers in gas hydrate bearing environments (Knittel et al., 2005). The ANME-2a clones were highly similar to sequences from other seep sites (Fig. 5), e.g. the Santa Barbara Basin Orphan et al., 2001a), Hydrate Ridge (Knittel et al., 2005), the Gulf of Mexico seeps (Mills et al., 2003), and a Pacific carbon dioxide seep (Inagaki et al., 2006). Sequences related to other groups performing AOM, such as ANME-1, -2c, -3, were not found at Gullfaks. One archaeal sequence belonged to the Marine Benthic Group D. Of the 6 crenarchaeotal sequences found in the library, three belonged to the Marine Benthic Group B. Both marine benthic groups are regularly found at seeps but their function remains unknown (Knittel et al., 2005; Teske et al., 2002; Niemann et al., 2006). Total cell numbers in surface sediments at the Heincke Seep, Gullfaks, were high with $6.7 \times 10^{9}$ and $7.9 \times 10^{9}$ single cells $\mathrm{ml}^{-1}$ sediment in the uppermost $10 \mathrm{~cm}$ at station 771 and 766, respectively (Table 4). These cell numbers are higher than previously reported for nonseep sandy sediments in the North Sea $\left(0.2-3.0 \times 10^{9}\right.$ cells; Llobet-Brossa et al., 1998; Wieringa et al., 2000; Rusch et al., 2001, 2003) and underline the stimulating effect of methane seepage on the density of the microbial community inhabiting sands. The only other published cell counts from 


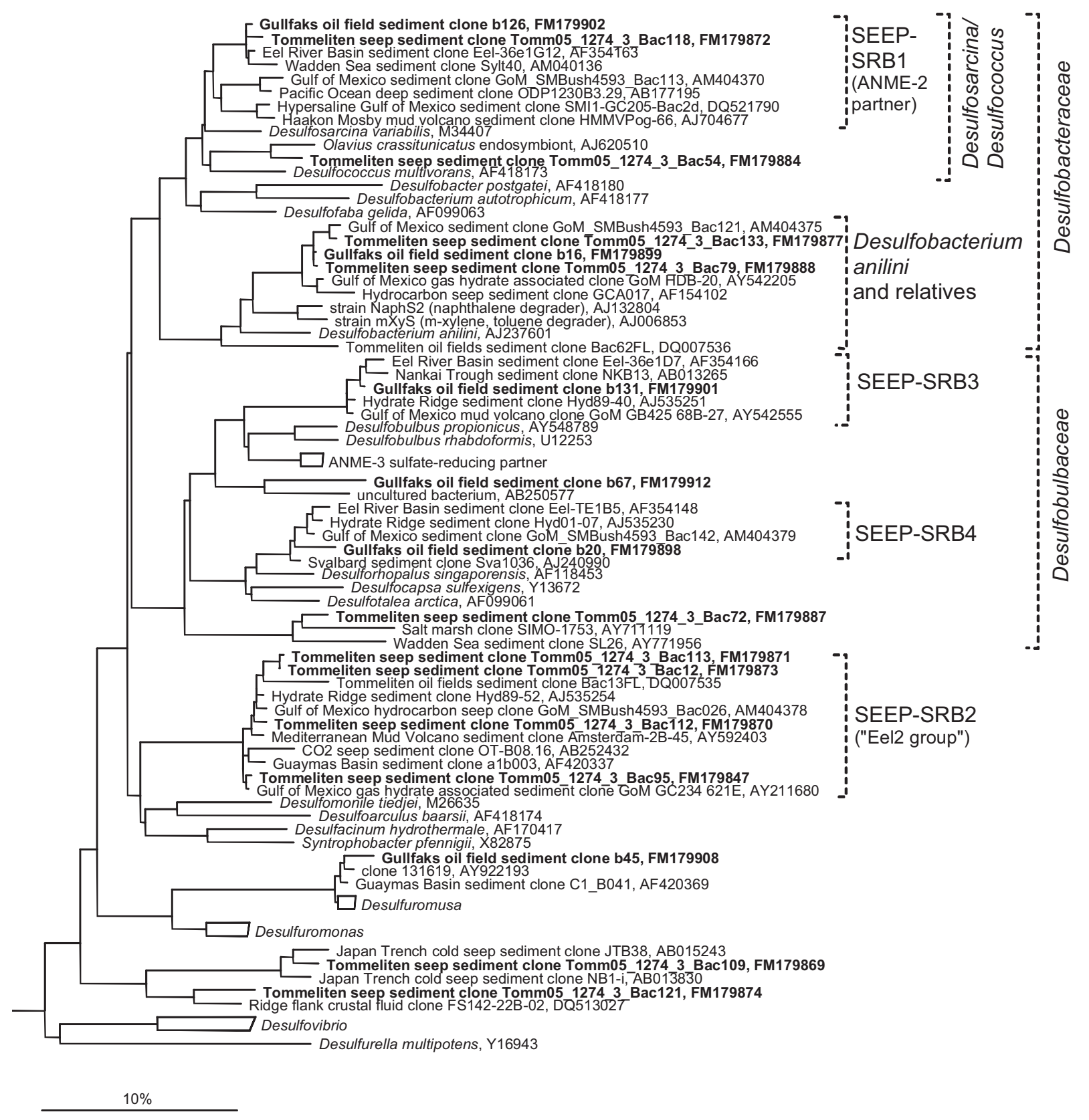

Fig. 4. Phylogenetic tree showing the affiliations of bacterial 16S rRNA clone sequences from Gullfaks and Tommeliten to selected references of the Deltaproteobacteria. The tree was calculated on a subset of nearly full-length sequences by maximum-likelihood analysis in combination with filters, which considered only 50\% conserved regions of the $16 \mathrm{~S}$ rRNA of $\delta$-proteobacteria to exclude the influence of highly variable positions. Partial sequences were inserted into the reconstructed tree by using parsimony criteria with global-local optimization, without allowing changes in the overall tree topology. Probe specificity is indicated by brackets. The bar represents $10 \%$ estimated sequence divergence. Sequences from this study are written in bold.

methane percolated sands showed numbers similar to those found at the Heincke Seep (Ishii et al., 2004). Here, at a depth of $20-30 \mathrm{~cm}$, cell numbers decreased considerably to $0.9 \times 10^{9}$ and $1.3 \times 10^{9}$ cells $\mathrm{ml}^{-1}$, indicating that the highest biomass may be associated with the peak of microbial activ- ity in the upper $10 \mathrm{~cm}$. The relative abundance of bacterial and archaeal cells was quantified by CARD-FISH. Bacteria comprised up to 50\% and single cell archaea between 6 and $16 \%$ of the DAPI-stained cells at Gullfaks, station 771 (Table 4). Aggregate numbers of ANME-2a and ANME-2c were 

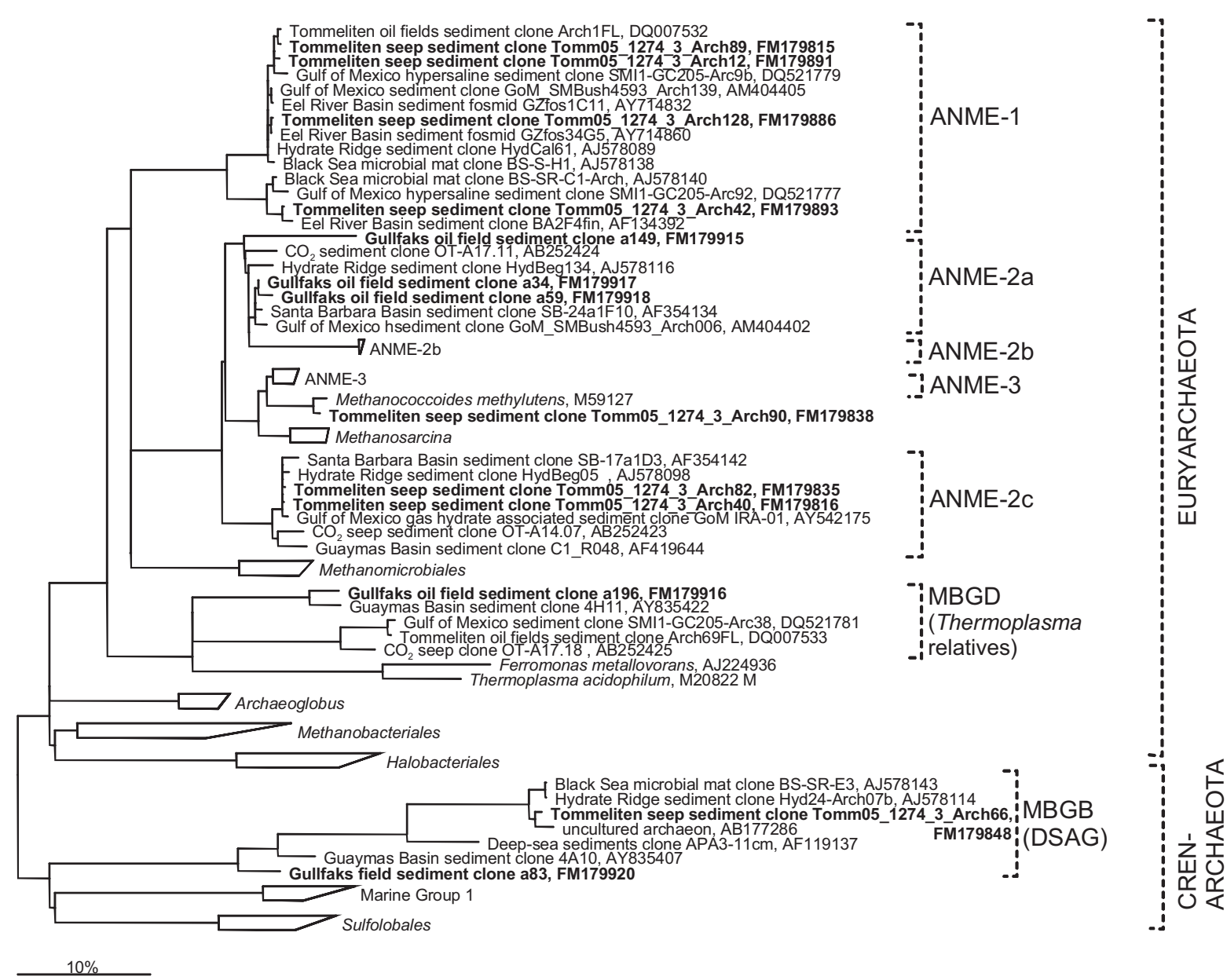

Fig. 5. Phylogenetic tree showing the affiliations of archaeal 16S rRNA gene sequences retrieved from sediments underlying the microbial mats of Gullfaks and Tommeliten to selected references of the domain Archaea. Besides cultivated organisms, at least one representative per phylogenetic group of all previously published clone sequences from methane-rich sites is included as reference. The tree was constructed by using maximum-likelihood analysis in combination with filters excluding highly variable positions. Partial sequences were inserted into the reconstructed tree by using parsimony criteria with global-local optimization, without allowing changes in the overall tree topology. Probe specificity is indicated by brackets. The bar represents $10 \%$ estimated sequence divergence. Sequences from this study are written in bold.

highest in the upper ten centimeters (up to $6.6 \times 10^{6}$ ANME$2 \mathrm{a}$ and $8.4 \times 10^{6}$ ANME-2c). However, their total number was about 20 -fold lower in comparison to deep water seep sites such as Hydrate Ridge (Knittel et al., 2005). ANME2a cells were clustering in dense, typically spherical aggregates associated with sulfate-reducing bacteria in diameters of up to $10 \mu \mathrm{m}$, while ANME-2c aggregates were less dense and smaller (Fig. 6). The highest counts of ANME aggregates and single ANME cells were in the top $10 \mathrm{~cm}$, matching the distribution of total cell numbers. This may indicate that the highest availability of both methane and sulfate as main source to the community is found at the surface of the seabed.
The Heincke Seep at Gullfaks is the first site at which abundant single cells of ANME-2a and ANME-2c were detected. Previously, only ANME-1 (Orphan et al., 2002; Niemann et al., 2005) and ANME-3 (Lösekann et al., 2007) were found as single cells. Monospecific ANME-2a or ANME-2c aggregates have been previously reported from Eckernförder Bay (Treude et al., 2005b) and Eel River Basin (Orphan et al., 2002). ANME-2 cell aggregates without bacterial partner were also found to dominate specific regions of a microbial mat from the Black Sea (Treude et al., 2007). 
Table 3. Overview of bacterial and archaeal 16S rRNA gene libraries and number of clones retrieved for the individual phylogenetic groups. Gullfaks (HE 208, MUC 766, 0-10 cm); Tommeliten (bacterial patch 4-6 cm, AL 267 1274 K3-2) and Tommeliten deep SMTZ sulfate methane transition zone (HE $1801904,160 \mathrm{~cm}$, Niemann et al., 2005).

\begin{tabular}{|c|c|c|c|c|}
\hline \multicolumn{2}{|l|}{ Bacteria } & \multirow{2}{*}{$\begin{array}{c}\text { Gullfaks } \\
1\end{array}$} & \multirow{2}{*}{$\begin{array}{c}\text { Tommeliten (bact. patch) } \\
1\end{array}$} & \multirow{2}{*}{ Tommeliten (deep SMTZ) } \\
\hline Alphaproteobacteria & & & & \\
\hline Gammaproteobacteria & Methylomonas & 4 & & \\
\hline & Methylophaga & 2 & & \\
\hline & Rel. of sulfur-oxidizing symbionts & 15 & & \\
\hline & Thioalkalivibrio, Thioploca rel. & & 18 & \\
\hline & Oceanospirillales & & 1 & \\
\hline \multirow[t]{9}{*}{ Deltaproteobacteria } & Seep-SRB1 & 1 & 3 & 51 \\
\hline & Seep-SRB2 & & & 3 \\
\hline & Seep-SRB3 & 3 & & \\
\hline & Seep-SRB4 & 1 & & \\
\hline & Desulfobacterium aniline rel. & 4 & 3 & 4 \\
\hline & Desulfobacter rel. & & 1 & 2 \\
\hline & Desulfobulbus rel. & 1 & 28 & \\
\hline & Myxobacteriales rel. & & 11 & \\
\hline & Desulfuromonas rel. & 1 & & \\
\hline Epsilonproteobacteria & & 3 & 2 & \\
\hline Spirochaeta & & & 1 & \\
\hline Cytophaga/Flavobacterium/Bacteriodetes & & 19 & 4 & 3 \\
\hline Planctomycetales & & & 3 & 4 \\
\hline Verrucomicrobia & Victivalliaceae & 3 & 1 & 36 \\
\hline Nitrospira & & & 1 & 6 \\
\hline Holophaga/Acidobacterium & & 4 & 10 & \\
\hline Nitrospina & & 2 & & \\
\hline OP11 & & 1 & & \\
\hline Actinobacteria & & 2 & 6 & \\
\hline Firmicutes & Desulfotomaculum rel. & 3 & 1 & \\
\hline Thermomicrobia & & & 3 & \\
\hline Cyanobacteria & & & 1 & \\
\hline \multirow[t]{2}{*}{ unaffiliated } & & & 3 & 3 \\
\hline & Total bacterial clones analyzed & 70 & 102 & 117 \\
\hline \multicolumn{5}{|l|}{ Archaea } \\
\hline \multirow[t]{5}{*}{ Euryarchaeota } & ANME-1 & & 17 & 16 \\
\hline & ANME-2a & 63 & & \\
\hline & ANME-2c & & 81 & \\
\hline & Marine Benthic Group D & 1 & & 1 \\
\hline & Methanococcoides & & 1 & \\
\hline \multirow[t]{3}{*}{ Crenarchaeota } & Marine Benthic Group B & 3 & 1 & \\
\hline & Marine Group 1 & 2 & & \\
\hline & Total archaeal clones analyzed & 69 & 100 & 17 \\
\hline
\end{tabular}

\subsection{Tommeliten seeps}

\subsubsection{Seafloor observations}

At Tommeliten, several gas flares extending from the seafloor to the sea surface were found in an area of roughly $0.5 \mathrm{~km}^{2}$ (Fig. 2f). Many of these flares were concentrated in a smaller area of about $0.06 \mathrm{~km}^{2}$, which could be the center of the subsurface gas escape pathway. The distribution of gas flares in 2005 (AL 267) was similar to the observations made in 2002 (HE 180; Niemann et al., 2005).
Our observations by ROV in 2005 confirmed that most gas flares originated from small holes $(1-5 \mathrm{~cm}$ diameter) in the seafloor emitting single streams of bubbles. The gas seeps were associated with small patches of bacterial mats (30$50 \mathrm{~cm}$ in diameter, Fig. 3b). The presence of free gas in these areas indicated dissolved methane saturation concentrations of $>12 \mathrm{mM}$ in sediments surrounding the spots of gas emission. As a consequence of the high gas content, the three sediment cores sampled from bacterial mats at Tommeliten strongly degassed upon recovery. Surface sediments at these 
Table 4. In situ quantification of different microbial groups using CARD-FISH. The specific probes used for CARD-FISH are listed in Materials and Methods.

\begin{tabular}{|c|c|c|c|c|c|c|c|c|c|c|c|}
\hline \multirow[b]{2}{*}{ Depth (cm) } & \multirow{2}{*}{$\begin{array}{l}\text { Total single cells } \\
\qquad\left(10^{9} \mathrm{~cm}^{-1}\right) \\
\text { +std.-deviation }\end{array}$} & \multicolumn{2}{|c|}{ Bacteria (single cells) } & \multicolumn{5}{|c|}{ Archaea (single cells) } & \multicolumn{3}{|c|}{ Archaea (aggregates) } \\
\hline & & $\begin{array}{c}\text { Bacteria \% } \\
\text { of TCC }\end{array}$ & $\begin{array}{l}\text { DSS \% } \\
\text { of TCC }\end{array}$ & $\begin{array}{c}\text { Archaea \% } \\
\text { of TCC }\end{array}$ & $\begin{array}{l}\text { ANME-1 \% } \\
\text { of TCC }\end{array}$ & $\begin{array}{c}\text { ANME- } 2 \mathrm{a} \% \\
\text { of TCC }\end{array}$ & $\begin{array}{c}\text { ANME- } 2 \mathrm{c} \% \\
\text { of TCC }\end{array}$ & $\begin{array}{l}\text { ANME-3 \% } \\
\text { of TCC }\end{array}$ & $\begin{array}{l}\text { ANME-2a } \\
\left(10^{6} \mathrm{~cm}^{-3}\right)\end{array}$ & $\begin{array}{l}\text { ANME-2c } \\
\left(10^{6} \mathrm{~cm}^{-3}\right)\end{array}$ & $\begin{array}{l}\text { ANME-3 } \\
\left(10^{6} \mathrm{~cm}^{-3}\right)\end{array}$ \\
\hline \multicolumn{12}{|l|}{ Gullfaks 766} \\
\hline $0-10$ & $7.9(2.8)$ & 46 & 8 & 12 & $<0.1$ & 2 & 2 & 0 & 5.6 & 8.4 & n.a. \\
\hline $10-20$ & $3.0(0.8)$ & 37 & 12 & 10 & $<0.1$ & 1 & 2 & 0 & 4.8 & 4.8 & n.a. \\
\hline $20-30$ & $0.9(0.3)$ & 39 & 7 & n.a. & 0.5 & 0 & $<1$ & 0 & 0 & 0 & n.a. \\
\hline \multicolumn{12}{|l|}{ Gullfaks 771} \\
\hline $0-10$ & $6.7(1.5)$ & 50 & 18 & 8 & $<0.1$ & $<1$ & $<1$ & 0 & 6.6 & 0.4 & n.a. \\
\hline $10-20$ & $3.6(0.7)$ & 26 & 29 & 8 & $<0.1$ & 0.9 & $<0.5$ & 0 & 0.8 & 0.4 & n.a. \\
\hline $20-30$ & $1.3(0.3)$ & 29 & 31 & 16 & $<0.1$ & 0 & 0 & 0 & 0.6 & 0 & n.a. \\
\hline \multicolumn{12}{|l|}{$\begin{array}{l}\text { Tommeliten } \\
\text { 1274-K1 }\end{array}$} \\
\hline $\begin{array}{l}0-3 \\
\text { Tommeliten } \\
1274-\mathrm{K} 2\end{array}$ & $4.0(0.7)$ & 69 & 25 & 10 & $<1$ & $<1$ & 2 & $<0.5$ & 1 & 0 & 0 \\
\hline $\begin{array}{l}0-3 \\
\text { Tommeliten } \\
\text { 1274-K3 }\end{array}$ & $5.0(1.0)$ & 74 & 20 & 4 & 1 & 2 & 2 & 1 & 1.1 & 0 & 0 \\
\hline $0-3$ & $5.7(1.0)$ & 71 & 28 & 13 & 2 & 1 & 0 & 1 & 1.6 & 0 & $*$ \\
\hline $3-6$ & $3.5(1.0)$ & 80 & 28 & 7 & n.a. & $<0.1$ & 0 & 5 & 2.7 & 0 & * \\
\hline $6-10$ & $2.9(0.6)$ & 91 & 34 & 4 & 4 & $<0.1$ & 0 & 2 & 0.9 & 0 & * \\
\hline
\end{tabular}

n.a.: not analyzed

* present, but not countable

spots consisted of fine-grained sand which contained little TOC of 0.22 to $0.32 \% \mathrm{w} / \mathrm{w}$.

\subsubsection{Methane and sulfate turnover}

Due to the small amount of sediment recovered, we could not measure AOM and SR rates of the bacterial mat covered sediments. In the subsurface sulfate methane transition zones (SMTZ), Niemann et al. (2005) showed low AOM and SR rates of a few nmol cm $\mathrm{cm}^{-3} \mathrm{~d}^{-1}$, resulting in ca. $50 \mathrm{~g} \mathrm{CH}_{4} \mathrm{~m}^{-2} \mathrm{yr}^{-1}\left(0.3 \mathrm{t} \mathrm{yr}^{-1}\right.$ for the whole seep area of ca. $6500 \mathrm{~m}^{2}$ ). In comparison, the methane leakage from Tommeliten was estimated with $47 \mathrm{~g} \mathrm{CH}_{4} \mathrm{~m}^{-2} \mathrm{yr}^{-1}$ (Hovland et al., 1993) suggesting a 50\% efficiency of the microbial filter against methane. The higher methane consumption efficiency compared to Gullfaks could be due to the impermeable nature of the Tommeliten sediments allowing free gas migration to the water column from only a few small gas vents (Fig. 3b).

\subsubsection{Biomarker and carbon isotope composition}

Similar to surface sediments of the Heincke Seep at Gullfaks, monounsaturated FAs were the dominant biomarker fraction in the surface sediments from the Tommeliten gas vents (Table 2). However, concentrations of these and other bacteria lipids were lower in comparison. The fatty acid distribution suggests the presence of sulfur-oxidizing bacteria, but the ratio of $\mathrm{C}_{16: 1 \omega 7 c}$ to $\mathrm{C}_{18: 1 \omega 7 c}$ to $\mathrm{C}_{16: 0}$ (42:32: 26) indicated a lower contribution to total bacterial biomass than in the Gullfaks sands. Also, the ratio of $\mathrm{C}_{16: 1 \omega 5 c}$ rel. to $\mathrm{i}-\mathrm{C}_{15: 0}$ and the presence of substantial amounts of cy- $\mathrm{C}_{17: \omega 5.6}$ in combina- tion with low $\delta^{13} \mathrm{C}$-values of these compounds indicates an origin from Seep-SRB1 associated with ANME-2 (Elvert et al., 2003; Niemann and Elvert 2008). However, similar to Gullfaks, the inconsistent distribution of $\delta^{13} \mathrm{C}$-values of FAs putatively specific for SRB, indicates a mixed community of SRB, of which a substantial fraction may not be involved in AOM. In contrast to Gullfaks, no indication for aerobic methanotrophs was found. This may be due to the reduced permeability for oxygenated bottom water in the silty, matcovered sand patches around the gas vents.

In comparison to the Heincke Seeps, the sediments from the Tommeliten gas vents contained similar amounts of archaeol but even more sn2-hydroxyarchaeol, indicating the dominance of ANME-2 populations (Blumenberg et al., 2004; Elvert et al., 2005; Niemann and Elvert, 2008). Both archaeol and sn2-hydroxyarchaeol were less depleted in ${ }^{13} \mathrm{C}$ than at Gullfaks with $\delta^{13} \mathrm{C}$-values of $-86 \%$ and $-90 \%$ o. However, considering the heavier isotope composition of the source methane at Tommeliten $\left(\delta^{13} \mathrm{C} \mathrm{CH}_{4}-46 \%\right.$; Hovland, 2002), the stable carbon isotope fractionation of the archaeal lipid biomass relative to source methane is $>40 \%$ o which is typical for ANME-2 populations (Niemann and Elvert, 2008) and comparable to the fractionation factor observed at Gullfaks.

Interestingly, the surface seep sediments at Tommeliten resembled the biomarker patterns in the authigenic carbonate outcrops, but differed substantially from subsurface sediments (Niemann et al., 2005). In the deep SMTZ Niemann et al. (2005) found a dominance of ANME-1 communities as indicated by the dominance of archaeol over sn2hydroxyarchaeol and a typical fatty acid pattern typical for 

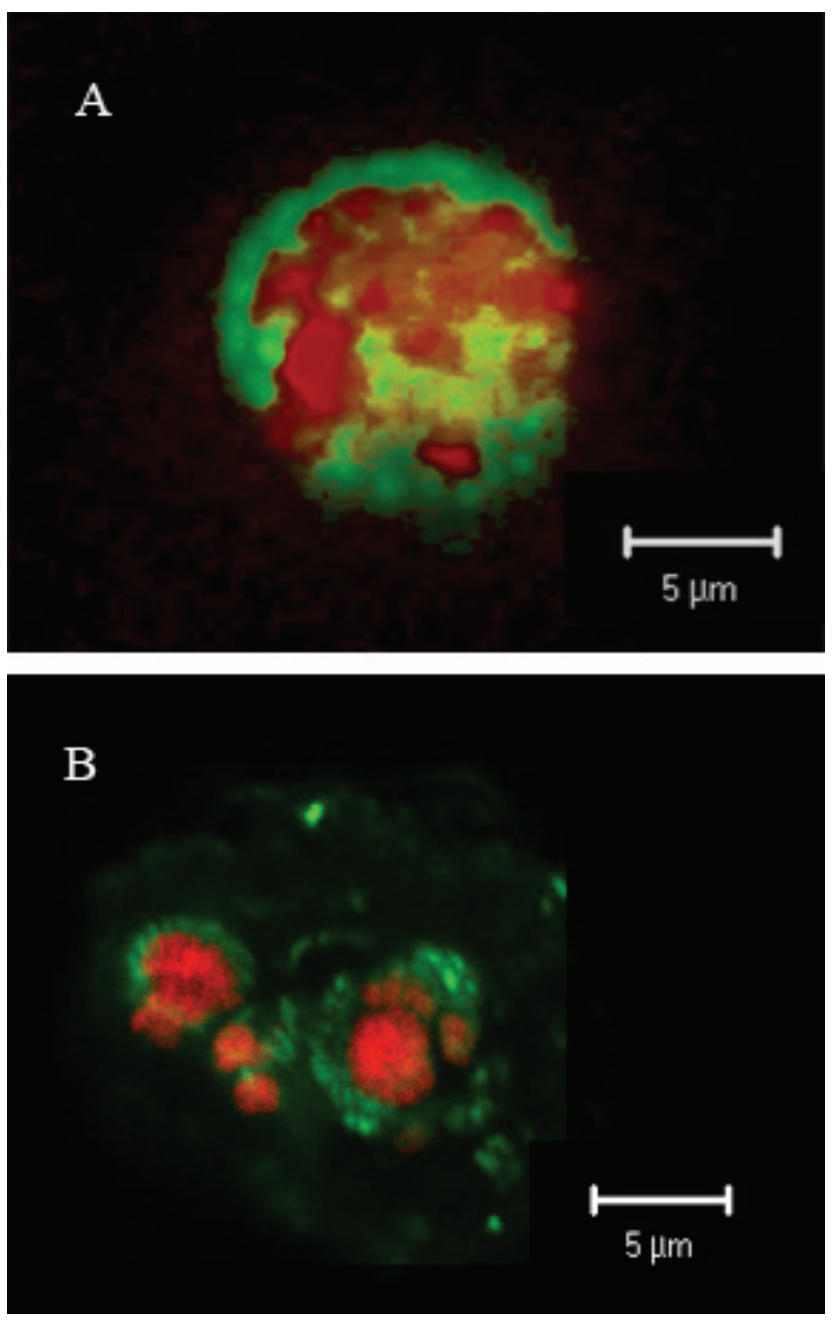

Fig. 6. Dual hybridizations with fluorescently labeled rRNA targeting oligonucleotide probes. (A) Consortia of ANME-2a/DSS from Gullfaks (probes ANME2a-647 [red] and DSS658 [green]); (B) Consortia of ANME-2c/DSS from Tommeliten (probes ANME2c622 [red] and DSS-658 [green]).

sulfate-reducing partners of ANME-1 (Niemann et al., 2005; Niemann and Elvert, 2008). These results correlated with 16S rRNA and FISH analyses (Niemann et al., 2005). From these and our results we conclude that ANME-1 could be adapted to the low energy conditions characteristic for deep sulfate methane transition zones, whereas ANME-2 dominate advection driven, highly active surface zones of gas vents as already observed in some deep water seeps (Knittel et al., 2005).

\subsubsection{Microbial diversity and community composition} based on 16S rRNA gene analyses

Similar to the Heincke Seep at Gullfaks, the bacterial 16S rRNA gene sequence library (Table 3 ) and the selected sequences in the phylogenetic tree (Fig. 4) obtained from sed- iments of Tommeliten showed a relatively high diversity of sulfate-reducing bacteria. We found three sequences of the uncultured Seep-SRB1 (ANME-2 partners) and 29 sequences of Desulfobulbus, which is known as the bacterial partner of ANME-3 (Haakon Mosby mud volcano, Barents Sea; Niemann et al., 2006; Lösekann et al., 2007). Single ANME-3 cells and a few aggregates occurred in the Tommeliten cold seep sediments, but their abundance was too low to analyze the potential bacterial partners. Three sequences of relatives of Desulfobacterium anilini were retrieved. These bacteria have been shown to oxidize different aromatic hydrocarbons such as naphthalene or xylene and could also have a function in hydrocarbon degradation at this site (for an overview see Widdel et al., 2007). Eighteen sequences related to Thioalkalivibrio and Thioploca were found which are mostly sulfide oxidizers.

As predicted by the biomarker patterns, the archaeal gene sequence library of Tommeliten contained mainly relatives of ANME-2c (83 sequences) and to a lower degree ANME1 (17 sequences, Table 3, Fig. 5). These were most closely related to sequences retrieved from gas hydrate bearing sediments such as the Eel River Basin, Hydrate Ridge, and the Gulf of Mexico. ANME-2a sequences were not represented in the clone library, although ANME-2a aggregates were detected by CARD-FISH (see below).

Cell counts in the cores $1274 \mathrm{~K} 1$ to $\mathrm{K} 3$ ranged from 4.1 to $5.8 \times 10^{9}$ cells ml ${ }^{-1}$ in the top layer of sediment and are hence comparable to the cell numbers at Gullfaks. With depth, cell numbers decreased to $2.9 \times 10^{9}$ cells ml $^{-1}$ (6$10 \mathrm{~cm}$ ). Quantification with CARD-FISH indicated the presence of ANME-2a, ANME-2c and low numbers of ANME-3 single cells and aggregates (Table 4). Sulfate reducing bacteria were highly abundant comprising up to one third of total single cells.

Hence, the microbial communities in mat-covered gassy surface sediments of both North Sea seeps were dominated by the ANME-2 cluster and their partner SRB. At Tommeliten, the AOM community in surface sediments of the gas vents was different from the community of the subsurface SMTZ (Niemann et al., 2005), but similar to those from active zones of gas emission, such as the one preserved in the authigenic carbonates, and the one from the Heincke Seep. The microbial communities also comprised sequences from other microorganisms typically occurring in methane rich deep-water seep ecosystems such as the crenarchaeotal Marine Benthic Group B. Gene libraries and CARD-FISH counts indicated also differences between Gullfaks and Tommeliten AOM communities - such as the dominance of the ANME-2a cluster in Gullfaks cold seep sediments and the dominance of ANME-2c at Tommeliten, which may be a result of the different geological and hydrological features of both sites. 


\section{The North Sea seeps in comparison to deep water cold seeps}

In the interstitial pore waters of the Tommeliten and Gullfaks seeps, dissolved methane can reach concentrations of $12 \mathrm{mM}$ and $25 \mathrm{mM}$, respectively. Since the hydrostatic pressure is too low to allow gas hydrate formation, emission of gaseous methane is favored. Due to their shallow depth, the North Sea seeps may be responsible for a substantial export of methane to the atmosphere. It would be an important future task to attempt quantification of gas emission to the atmosphere by monitoring flares, methane concentrations and consumption in the flares and the surrounding water column and the gas flux from the overlying surface waters to the atmosphere. Especially highly permeable sands such as at Gullfaks facilitate the migration of gas bubbles through the seabed. The high upward advection of gas may even restrict the downward diffusion of oxygenated bottom waters below a few $\mathrm{cm}$, protecting the anaerobic methanotrophic communities from oxygenation. In contrast, the compact silty sands of Tommeliten allow gas migration only through small cracks in the seafloor sediments, restricting the distribution of methanotrophs and thiotrophs to small patches around the gas vents. Phylogenetic analysis of Deltaproteobacteria and Euryarchaeota at Gullfaks and Tommeliten indicate a high similarity of these to sequences from deep water seep sites, such as Hydrate Ridge (Boetius et al., 2000; Knittel et al., 2003, 2005), Eel River Basin (Orphan et al., 2001a, b) or Guyamas Basin (Teske et al., 2002).

Although the signature of the AOM specific biomarker were similar to those of deep water seep ecosystems, the biomarker concentrations at the North Sea seeps were about one order of magnitude lower (e.g. $\mathrm{C}_{16: 1 \omega 5 c}$ up to $26.5 \mu \mathrm{g} \mathrm{gdw}^{-1}$ at Hydrate Ridge; Elvert et al., $2003 \mathrm{com}$ pared to 3.8 and $0.4 \mu \mathrm{g} \mathrm{gdw}^{-1}$ at Gullfaks and Tommeliten). This finding was reflected in the low number of ANME aggregates of around $10^{6} \mathrm{~cm}^{-3}$. In deep water cold seeps such as Hydrate Ridge, Haakon Mosby and Eel River Basin, ANME aggregate numbers reach $10^{8}$, comprising a large fraction of the total microbial biomass $(>90 \%$; Knittel et al., 2005). A reason for this difference in ANME biomass could be the higher availability of dissolved methane in deep water seeps due to the increased solubility of methane at high hydrostatic pressures. Previous experiments indicate that AOM rates and the energy yield available for growth could be higher at elevated methane concentrations (Nauhaus et al., 2002, 2007). A second explanation for lower aggregate abundances at the North Sea seeps may be the high bottom water currents causing relocation of particles and sporadic oxygen influx into the sediments, and higher grazing rates. The only shallow water seeps known with higher biomass of ANME compared to deep seeps are the conspicuous methanotrophic microbial reefs of the Black Sea (Blumenberg et al., 2004; Treude et al., 2005a). However, these lie in permanently anoxic waters and are hence protected from such en- vironmental disturbances.

Acknowledgements. This study was conducted as part of the METROL project (http://www.metrol.org) of the 5th framework program of the European Commission (EVK-3-CT-2002-00080). We thank captain, crew and shipboard scientists of R/V Heincke cruise HE-169 HE-180 and HE-208 and R/V Alkor cruise AL-267 for their excellent support of work at sea. We thank Gert Wendt, Jens Wunderlich (INNOMAR), Julian Gutt, Ingrid Vöge (AWI), Frank Wenzhöfer, Marc Viehweger, Viola Beier, Tomas Wilkop, Imke Busse (MPI), Nico Nowald (MARUM) as well as Regina Usbeck, Werner Dimmler, Steffen Gauger (FIELAX) for technical support and laboratory work, and Alan Judd and Dave Long for important information on seep structures of the North Sea, as well as two reviewers for helpful comments on an earlier version of this manuscript.

Edited by: K. Küsel

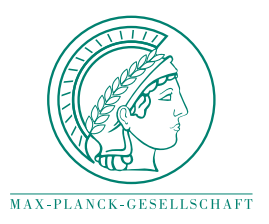

The publication of this article is financed by the Max Planck Society.

\section{References}

Amann, R. I., Krumholz, L., and Stahl, D. A.: Fluorescentoligonucleotide probing of whole cells for determinative, phylogenetic, and environmental studies in microbiology, J. Bacteriol., 172(2), 762-770, 1990.

Blumenberg, M., Seifert, R., Reitner, J., Pape, T., and Michaelis, W.: Membrane lipid patterns typify distinct anaerobic methanotrophic consortia, P. Natl. Acad. Sci. USA, 101(30), $11111-$ $11116,2004$.

Boetius, A., Ravenschlag, K., Schubert, C. J., Rickert, D., Widdel, F., Gieseke, A., Amann, R., Jørgensen, B. B., Witte, U., and Pfannkuche, O.: A marine microbial consortium apparently mediating anaerobic oxidation of methane, Nature, 407, 623-626, 2000.

Daims, H., Bruhl, A., Amann, R., Schleifer, K. H., and Wagner, M.: The domain-specific probe EUB338 is insufficient for the detection of all bacteria: Development and evaluation of a more comprehensive probe set, Syst. Appl. Microbiol., 22(3), 434-444, 1999.

Dando, P. R., Bussmann, I., Niven, S. J., O’Hara, S. C. M, Schmaljohann, R., and Taylor, L. J.: A methane seep area in the Skagerrak, the habitat of the pogonophore Siboglinum poseidoni and the bivalve mollusc Thyasira sarsi, Mar. Ecol.-Prog. Ser., 107, 157-167, 1994.

Eisma, D. and Kalf, J.: Dispersal, concentration and deposition of suspended matter in the North Sea, J. Geol. Soc. London, 144(1), 161-178, 1987.

Elvert, M., Boetius, A., Knittel, K., and Jørgensen, B. B.: Characterization of specific membrane fatty acids as chemotaxonomic markers for sulfate-reducing bacteria involved in anaerobic oxidation of methane, Geomicrobiol. J., 20(4), 403-419, 2003. 
Elvert, M., Hopmans, E. C., Treude, T., Boetius, A., and Suess, E.: Spatial variations of methanotrophic consortia at cold methane seeps: implications from a high-resolution molecular and isotopic approach, Geobiology, 3(3), 195-209, 2005.

Elvert, M. and Niemann, H.: Occurrence of unusual steroids and hopanoids derived from aerobic methanotrophs at an active marine mud volcano, Org. Geochem., 39, 167-177, 2008.

Fang, J., Shizuka, A., Kato, C., and Schouten, S.: Microbial diversity of cold-seep sediments in Sagami Bay, Japan, as determined by $16 \mathrm{~S}$ rRNA gene and lipid analyses, FEMS Microbiol. Ecol., 57(3), 429-441, 2005.

Hinrichs, K.-U., Hayes, J. M., Silva, S. P., Brewer, P. G. and DeLong, E. F.: Methane-consuming archaebacteria in marine sediments, Nature, 398, 802-805, 1999.

Hinrichs, K.-U. and Boetius, A.: The anaerobic oxidation of methane: New insights in microbial ecology and biogeochemistry, in: Ocean margin systems, edited by: Wefer, G., Billett, D., and Hebbeln, D., Springer-Verlag, Berlin and Heidelberg, Germany, 457-477, 2002.

Hovland, M.: On the self-sealing nature of marine seeps, Cont. Shelf. Res., 22(16), 2387-2394, 2002.

Hovland, M.: Discovery of prolific natural methane seeps at Gullfaks, northern North Sea, Geo-Mar. Lett., 27(2), 197-201, 2007.

Hovland, M., Gardner, J. V., and Judd, A. G.: The significance of pockmarks to understanding fluid flow processes and geohazards, Geofluids, 2(2), 127-136, 2002.

Hovland, M. and Judd, A. G.: Seabed pockmarks and seepages, Graham and Trotham, London, UK, 293 pp., 1988.

Hovland, M., Judd, A. G., and Burke Jr., R. A.: The global flux of methane from shallow submarine sediments, Chemosphere, 26(1-4), 559-578, 1993.

Hovland, M. and Risk, M.: Do Norwegian deep-water coral reefs rely on seeping fluids?, Mar. Geol., 198(1-2), 83-96, 2003.

Hovland, M. and Sommerville, J. H.: Characteristics of two natural gas seepages in the North Sea, Mar. Petrol. Geol., 2, 319-326, 1985.

Inagaki, F., Kuypers, M. M. M., Tsunogai, U., Ishibashi, J., Nakamura, K. Treude, T., Ohkubo, S., Nakaseama, M., Gena, K., Chiba, H., Hirayama, H., Nunoura, T., Takai, K., Jørgensen, B. B., Horikoshi, K., and Boetius, A.: Microbial community in a sediment-hosted $\mathrm{CO}_{2}$ lake of the southern Okinawa Trough hydrothermal system, P. Natl. Acad. Sci. USA, 103(38), 14164 $14169,2006$.

Ishii, K., Mussmann, M., MacGregor, B. J., and Amann, R.: An improved fluorescence in situ hybridization protocol for the identification of bacteria and archaea in marine sediments, FEMS Microbiol. Ecol., 50(3), 203-212, 2004.

Jørgensen, B. B. and Fenchel, T.: The sulfur cycle of a marine sediment model system, Mar. Biol., 24(3), 189-201., 1974.

Joye, S. B., Boetius, A., Orcutt, B. N., Montoya, J. P., Schulz, H. N., Erickson, M. J., and Lugo, S.: The anaerobic oxidation of methane and sulfate reduction in sediments from Gulf of Mexico cold seeps, Chem. Geol., 205, 219-238, 2004.

Judd, A. G., Hovland, M., Dimitrov, L. I., Garcia Gil, S., and Jukes, V.: The geological methane budget at continental margins and its influence on climate change, Geofluids, 2, 109-126, 2002.

Judd, A. and Hovland, M.: Seabed fluid flow: the impact on geology, biology and the marine environment, Cambridge University Press, Cambridge, UK, 492 pp., 2007.
Kallmeyer, J., Ferdelman, T. G., Weber, A., Fossing, H., and Jørgensen, B. B.: A cold chromium distillation procedure for radiolabeled sulfide applied to sulfate reduction measurements, Limnol. Oceanogr.-Meth., 2, 171-180, 2004.

Kane, M. D., Poulsen, L. K., and Stahl, D. A.: Monitoring the enrichment and isolation of sulfate-reducing bacteria by using oligonucleotide hybridization probes designed from environmentally derived 16S rRNA sequences, Appl. Environ. Microb., 59, 682-686, 1993.

Knittel, K., Boetius, A., Lemke, A., Eilers, H., Lochte, K., Pfannkuche, O., Linke, P., and Amann, R.: Activity, distribution, and diversity of sulfate reducers and other bacteria in sediments above gas hydrate (Cascadia margin, Oregon), Geomicrobiol. J., 20(4), 269-294, 2003.

Knittel, K., Lösekann, T., Boetius, A., Kort, R., and Amann, R.: Diversity and distribution of methanotrophic archaea at cold seeps, Appl. Environ. Microb., 71(1), 467-479, 2005.

Krüger, M., Treude, T., Wolters, H., Nauhaus, K., and Boetius, A.: Microbial methane turnover in different marine habitats, Palaeogeogr. Palaeocl., 227, 6-17, 2005.

Lane, D. J., Pace, B., Olsen, G. J., Stahl, D. A., Sogin, M. L., and Pace, N. R.: Rapid determination of 16S ribosomal RNA sequences for phylogenetic analyses, P. Natl. Acad. Sci. USA, 82(20), 6955-6959, 1985.

Levin, L. A.: Ecology of cold seep sediments: Interactions of fauna with flow, chemistry and microbes, Oceanogr. Mar. Biol. Annu. Rev., 43, 1-46, 2005.

Llobet-Brossa, E., Rossello-Mora, R., and Amann, R.: Microbial community composition of Wadden Sea sediments as revealed by fluorescence in situ hybridization, Appl. Environ. Microb., 64(7) 2691-2696, 1998.

Lösekann, T., Knittel, K., Nadalig, T., Fuchs, B., Niemann, H., Boetius, A., and Amann, R.: Diversity and abundance of aerobic and anaerobic methane oxidizers at the Haakon Mosby Mud Volcano, Barents Sea, Appl. Environ. Microb., 73(10), 3348-3362, 2007.

Ludwig, W., Strunk, O., Westram, R., Richter, L., Meier, H., Yadhukumar, Buchner, A., Lai, T., Steppi, S., Jobb, G., Forster, W., Brettske, I., Gerber, S., Ginhart, A. W., Gross, O., Grumann, S., Hermann, S., Jost, R., Konig, A., Liss, T., Lussmann, R., May, M., Nonhoff, B., Reichel, B., Strehlow, R., Stamatakis, A., Stuckmann, N., Vilbig, A., Lenke, M., Ludwig, T., Bode, A., and Schleifer, K.-H.: ARB: a software environment for sequence data, Nucleic Acids Res., 32(4), 1363-1371, 2004.

Luff, R. and Wallmann, K.: Fluid flow, methane fluxes, carbonate precipitation and biogeochemical turnover in gas hydrate-bearing sediments at Hydrate Ridge, Cascadia Margin: Numerical modeling and mass balances, Geochim. Cosmochim. Ac., 67(18), 3403-3421, 2003.

Manz, W., Eisenbrecher, M., Neu, T. R., and Szewzyk, U.: Abundance and spatial organization of gram-negative sulfate-reducing bacteria in activated sludge investigated by in situ probing with specific 16S rRNA targeted oligonucleotides, FEMS Microbiol. Ecol., 25, 43-61, 1998.

Massana, R., Murray, A., Preston, C., and DeLong, E.: Vertical distribution and phylogenetic characterization of marine planktonic Archaea in the Santa Barbara Channel, Appl. Environ. Microb., 63(1), 50-56, 1997.

Meyer-Reil, L.-A.: Benthic response to sedimentation events during 
autumn to spring at a shallow water station in the Western Kiel Bight, Mar. Biol., 77(3), 247-256, 1983.

Michaelis, W., Seifert, R., Nauhaus, K., Treude, T., Thiel, V., Blumenberg, M., Knittel, K., Gieseke, A., Peterknecht, K., Pape, T., Boetius, A., Amann, R., Jørgensen, B. B., Widdel, F., Peckmann, J., Pimenov, N. V., and Gulin, M. B.: Microbial reefs in the Black Sea fueled by anaerobic oxidation of methane, Science, 297, 1013-1015, 2002.

Mills, H. J., Hodges, C., Wilson, K., MacDonald, I. R., and Sobecky, P. A.: Microbial diversity in sediments associated with surface-breaching gas hydrate mounds in the Gulf of Mexico, FEMS Microbiol. Ecol., 46(1), 39-52, 2003.

Moss, C. W. and Lambert-Fair, M. A.: Location of double bonds in monounsaturated fatty acids of Campylobacter cryaerophila with dimethyl disulfide derivatives and combined gas chromatography-mass spectrometry, J. Clin. Microbiol., 27(7), 1467-1470, 1989.

Muyzer, G., Teske, A., Wirsen, C. O., and Jannasch, H. W.: Phylogenetic relationships of Thiomicrospira species and their identification in deep-sea hydrothermal vent samples by denaturing gradient gel electrophoresis of 16S rDNA fragments, Arch. Microbiol., 164(3), 165-172, 1995.

Nauhaus, K., Boetius, A., Krüger, M., and Widdel, F.: In vitro demonstration of anaerobic oxidation of methane coupled to sulphate reduction in sediments from a marine gas hydrate area, Environ. Microbiol., 4(5), 296-305, 2002.

Nauhaus, K., Albrecht, M., Elvert, M., Boetius, A., and Widdel, F.: In vitro cell growth of marine archaeal-bacterial consortia during anaerobic oxidation of methane with sulfate, Environ. Microbiol., 9(1), 187-196, 2007.

Nelson, D. C. and Jannasch, H. W.: Chemoautotrophic growth of a marine Beggiatoa in sulfide-gradient cultures, Arch. Microbiol., 136(4), 262-269, 1983.

Nelson, D. C., Jørgensen, B. B., and Revsbech, N. P.:. Growth pattern and yield of a chemoautotrophic Beggiatoa sp. in oxygensulfide microgradients, Appl. Environ. Microb., 52(2), 225-233, 1986

Nelson, D. C., Wirsen, C. O., and Jannasch, H. W.: Characterization of large, autotrophic Beggiatoa spp. abundant at hydrothermal vents of the Guaymas Basin, Appl. Environ. Microb., 55(11), 2909-2917, 1989.

Niemann, H. and Elvert, M.: Diagnostic lipid biomarker and stable carbon isotope signatures of microbial communities mediating the anaerobic oxidation of methane with sulphate, Chem. Geol., in press, 2008.

Niemann, H., Elvert, M., Hovland, M., Orcutt, B., Judd, A., Suck, I., Gutt, J., Joye, S., Damm, E., Finster, K., and Boetius, A.: Methane emission and consumption at a North Sea gas seep (Tommeliten area), Biogeosciences, 2, 335-351, 2005 , http://www.biogeosciences.net/2/335/2005/.

Niemann, H., Lösekann, T., de Beer, D., Elvert, M., Nadalig, T., Knittel, K., Amann, R., Sauter, E. J., Schlüter, M., Klages, M., Foucher, J. P., and Boetius, A.: Novel microbial communities of the Haakon Mosby mud volcano and their role as a methane sink, Nature, 443, 854-858, 2006.

Omoregie, E. O., Mastalerz ,V., de Lange, G., Straub, K. L., Kappler, A., Røy, H., Stadnitskaia, A., Foucher, J. P., and Boetius, A.: Biogeochemistry and community composition of iron- and sulfur-precipitating microbial mats at the Chefren Mud Volcano
(Nile Deep Sea Fan, Eastern Mediterranean), Appl. Environ. Microb., 74(10), 3198-3215, 2008

Orphan, V. J., Hinrichs, K.-U., Ussler, W., Paull, C. K., Taylor, L. T., Sylva, S. P., Hayes, J. M., and Delong, E. F.: Comparative analysis of methane-oxidizing archaea and sulfate-reducing bacteria in anoxic marine sediments, Appl. Environ. Microb., 67(4), 1922-1934, 2001a.

Orphan, V. J., House, C. H., Hinrichs, K.-U., McKeegan, K. D., and DeLong, E. F.: Methane-consuming archaea revealed by directly coupled isotopic and phylogenetic analysis, Science, 293, 484487, $2001 b$.

Orphan, V. J., House, C. H., Hinrichs, K.-U., McKeegan, K. D., and DeLong, E. F.: Multiple archaeal groups mediate methane oxidation in anoxic cold seep sediments, P. Natl. Acad. Sci. USA, 99(11), 7663-7668, 2002.

Ourisson, G., Albrecht, P., and Rohmer, M.: The hopanoids, Paleochemistry and biochemistry of a group of natural products, Pure Appl. Chem., 51, 709-729, 1979.

Pernthaler, A., Pernthaler, J., and Amann, R.: Fluorescence in situ hybridization and catalyzed reporter deposition for the identification of marine bacteria, Appl. Environ. Microb., 68(6), 3094 3101, 2002.

Ravenschlag, K., Sahm, K., Pernthaler, J., and Amann, R.: High bacterial diversity in permanently cold marine sediments, Appl Environ. Microb., 65(9), 3982-3989, 1999.

Reeburgh, W.: Oceanic methane biogeochemistry, Chem. Rev., 107(2), 486-513, 2007.

Rehder, G., Keir, R. S., Suess, E., and Pohlmann, T.: The multiple sources and patterns of methane in North Sea waters, Aquat Geochem., 4(3), 403-427, 1998.

Rise, L., Saettem, J., Fanavoll, S., Thorsnes, T., Ottesen, D., and Boe, R.: Sea-bed pockmarks related to fluid migration from Mesozoic bedrock strata in the Skagerrak offshore Norway, Mar. Petrol. Geol., 16(7), 619-631, 1999.

Ritger, S., Carson, B., and Suess, E.: Methane-derived authigenic carbonates formed by subduction-induced pore-water expulsion along the Oregon/Washington margin, Geol. Soc. Am. Bull., 98(2), 147-156, 1987.

Rohmer, M., Bouvier-Nave, P., and Ourisson, G.: Distribution of hopanoid triterpenes in prokaryotes, J. Gen. Microbiol., 130, 1137-1150, 1984.

Rusch, A., Forster, S., and Huettel, M.: Bacteria, diatoms and detritus in an intertidal sandflat subject to advective transport across the water-sediment interface, Biogeochemistry, 55(1), 127, 2001.

Rusch, A., Huettel, M., Reimers, C. E., Taghon, G. L., and Fuller, C. M.: Activity and distribution of bacterial populations in Middle Atlantic Bight shelf sands, FEMS Microbiol. Ecol., 44(1), 89100,2003

Stahl, D. A. and Amann, R.: Development and application of nucleic acid probes, in: Nucleic acid techniques in bacterial systematics, edited by: Stackebrandt, E. and Goodfellow, M., John Wiley and Sons Ltd., Chichester, UK, 205-248, 1991.

Teske, A., Hinrichs, K. U., Edgcomb, V., de Vera Gomez, A., Kysela, D., Sylva, S. P., Sogin, M. L., and Jannasch, H. W.: Microbial diversity of hydrothermal sediments in the Guaymas Basin: evidence for anaerobic methanotrophic communities, Appl. Environ. Microb., 68(4), 1994-2007, 2002.

Trasher, J., Fleet, A. J., Hay, S. J., Hovland, M., and Düpenbecker, 
S.: Understanding geology as the key to using seepage in exploration: spectrum of seepage styles, in: Schumacher, D. and Abrams, M. A., Hydrocarbon migration and its near-surface expression, AAPG Memoir, 223-241, 1996.

Treude, T., Boetius, A., Knittel, K., Nauhaus, K., Elvert, M., Krüger, M., Lösekann, T., Wallmann, K., Jørgensen, B. B., Widdel, F., and Amman, R.: Anaerobic oxidation of methane at Hydrate Ridge (OR), Geochim. Cosmochim. Ac., 67(18), 491-491, 2003.

Treude, T., Knittel, K., Blumenberg, M., Seifert, R., and Boetius, A.: Subsurface microbial methanotrophic mats in the Black Sea, Appl. Environ. Microb., 71(10), 6375-6378, 2005a.

Treude, T., Krüger, M., Boetius, A., and Jørgensen, B. B.: Environmental control on anaerobic oxidation of methane in the gassy sediments of Eckernfoerde Bay (German Baltic), Limnol. Oceanogr., 50(6), 1771-1786, 2005b.

Treude, T., Orphan, V., Knittel, K., Gieseke, A., House, C., and Boetius, A.: Consumption of methane and $\mathrm{CO}_{2}$ by methanotrophic microbial mats from gas seeps of the anoxic Black Sea, Appl. Environ. Microbiol., 73, 2271-2283, 2007.
Valentine, D. L. and Reeburgh, W. S.: New perspectives on anaerobic methane oxidation, Environ. Microbiol., 2(5), 477-487, 2000.

Widdel, F. and Bak, F.: Gram-negative mesophilic sulfate-reducing bacteria, in: The prokaryotes, edited by: Balows, A., Dworkin, M., Harder, W., Schleifer, K.-H., Springer, Berlin and Heidelberg, Germany, and New York, USA, 3352-3378, 1992.

Widdel, F., Musat, F., Knittel, K., and Galushko, A.: Anaerobic degradation of hydrocarbons with sulphate as electron acceptor, in: Sulphate-reducing bacteria: environmental and engineered systems, edited by: Barton, L. L. and Hamilton, W. A., Cambridge University Press, Cambridge, UK, 265-304, 2007.

Wieringa, E. B. A., Overmann, J., and Cypionka, H.: Detection of abundant sulphate-reducing bacteria in marine oxic sediment layers by a combined cultivation and molecular approach, Environ. Microbiol., 2(4), 417-427, 2000.

Zhang, C. L., Huang, Z., Cantu, J., Pancost, R. D., Brigmon, R. L., Lyons, T. W., and Sassen, R.: Lipid biomarkers and carbon isotope signatures of a microbial (Beggiatoa) mat associated with gas hydrates in the Gulf of Mexico, Appl. Environ. Microb., 71(4), 2106-2112, 2005. 